University of Wollongong

Research Online

Faculty of Law, Humanities and the Arts Papers (Archive)

Faculty of Arts, Social Sciences \& Humanities

$1-1-2019$

Consonant Deletion and Eastern Andalusian Spanish Vowels: The Effect of Word-final /s/, /r/ and / $\boldsymbol{\theta} /$ Deletion on /i/

Alfredo Herrero de Haro

University of Wollongong, alfredo@uow.edu.au

Follow this and additional works at: https://ro.uow.edu.au/lhapapers

Part of the Arts and Humanities Commons, and the Law Commons

Research Online is the open access institutional repository for the University of Wollongong. For further information contact the UOW Library: research-pubs@uow.edu.au 


\title{
Consonant Deletion and Eastern Andalusian Spanish Vowels: The Effect of Word- final /s/, /r/ and / / / Deletion on /i/
}

\author{
Abstract \\ Syllable-final consonant deletion has been widely documented in Eastern Andalusian Spanish, although \\ the effects of consonant deletion on preceding vowels are still unknown. Studies analyzing syllable-final \\ consonants in Eastern Andalusian Spanish have focused on /-s/, disregarding other consonants which \\ are also deleted in this position. The present paper aims to extend this traditional focus by analyzing how \\ /-s/, /-r/ and /- $\theta /$ deletion affects preceding /i/. After analyzing 383 samples of /i/ word-finally and before \\ underlying word-final $/ \mathrm{s} /, / \mathrm{r} /$ and $/ \theta /$ in Western Almería (Eastern Andalusia), it is confirmed that the \\ deletion of these three consonants changes the quality of preceding /i/. Furthermore, the results of a \\ perception test confirm that speakers of Eastern Andalusian Spanish can identify whether or not $/ \mathrm{i} /$ is \\ followed by an underlying /-s/, /-r/ or /- $\theta$ / and they can also identify two types of /i/ in isolation: word-final \\ /i/ and /i/ preceding underlying /-r/; this identification occurs at a rate which is statistically significant. It \\ is hypothesized that, apart from vowel height and frontness, a suprasegmental feature could be the \\ perceptual cue used to identify an underlying consonant after a vowel in this variety of Spanish.

\section{Disciplines} \\ Arts and Humanities | Law

\section{Publication Details} \\ Herrero de Haro, A. (2019). Consonant Deletion and Eastern Andalusian Spanish Vowels: The Effect of \\ Word-final /s/, /r/ and / $\theta /$ Deletion on /i/. Australian Journal of Linguistics, 39 (1), 107-131. DOI: 10.1080/ \\ 07268602.2019 .1542935
}




\title{
Consonant deletion and Eastern Andalusian Spanish vowels:
}

The effect of word-final /s/, /r/, and / $/$ / deletion on /i/

\author{
Alfredo Herrero de Haro \\ University of Wollongong
}

\begin{abstract}
Syllable-final consonant deletion has been widely documented in Eastern Andalusian Spanish, although the effects of consonant deletion on preceding vowels are still unknown. Studies analyzing syllable-final consonants in Eastern Andalusian Spanish have focused on /-s/, disregarding other consonants which are also deleted in this position. The present paper aims to extend this traditional focus by analyzing how /-s/, /-r/, and /- $\theta /$ deletion affects preceding /i/. After analyzing 383 samples of /i/ word-finally and before underlying wordfinal $/ \mathrm{s} /, / \mathrm{r} /$, and $/ \theta /$ in Western Almería (Eastern Andalusia), it is confirmed that the deletion of these three consonants changes the quality of preceding /i/. Furthermore, the results of a perception test confirm that speakers of Eastern Andalusian Spanish can identify whether or not /i/ is followed by an underlying /-s/, /-r/, or /- $\theta$ / and they can also identify two types of /i/ in isolation: word-final /i/ and /i/ preceding underlying /-r/; this identification occurs at a rate which is statistically significant. It is hypothesized that, apart from vowel height and frontness, a suprasegmental feature could be the perceptual cue used to identify an underlying consonant after a vowel in this variety of Spanish.
\end{abstract}

Key words: Eastern Andalusian vowels, Eastern Andalusian Spanish, Spanish vowel system, deletion of consonants in coda, Andalusian Spanish phonetics and phonology.

This work was supported by a Hispanex grant from the Ministry of Education, Culture, and Sport (Spain), and by funds from the Faculty of Law, Humanities, and the Arts (University of Wollongong). 


\section{Introduction}

Eastern Andalusian Spanish (henceforth $E A S$ ) is the variety of Spanish spoken in Eastern Andalusia, which is comprised of the provinces of Almería, Granada, Jaén, and Córdoba (Jiménez Fernández 1999; Villena Ponsoda 2000; Moya Corral 2010). Coda consonant deletion has been extensively documented in this geolect by several researchers (e.g. Wulff 1889; Navarro Tomás 1938, 1939; Salvador 1957, 1977; Sanders 1994, 1998; Henriksen 2017); however, the effects of consonant deletion on neighbouring segments are still debated (Herrero de Haro 2016).

Although most consonants are deleted syllable-finally in EAS (Alvar et al. 1973; Rodríguez-Castellano and Palacio 1948a, 1948b; O’Neill 2010), researchers have focused on /-s/ due to its high functional load in Spanish (Gerfen and Hall 2001). For example, in Spanish, /-s/ can mark plurality (e.g. cosa 'thing' vs cosas 'things'), it can contrast second and third persons of verbs in some tenses (e.g. habla 'he/she talks' vs hablas 'you singular talk') and it can also differentiate between words ( $m e$ 'me, to me' vs mes 'month').

To date, the main reported consequence of /-s/ deletion on EAS vowels is "vowel opening" (Alvar et al. 1973: map 1696; Salvador 1977). According to many researchers (e.g. Navarro Tomás 1938, 1939; Corbin 2006; Peñalver Castillo 2006), vowels preceding /-s/ deletion undergo opening and this vowel opening marks an underlying/-s/. This vowel opening is used to differentiate Western Andalusian Spanish (henceforth WAS) from EAS (e.g. Villena Ponsoda 2000).

Previous studies have focused on /Vowel/ vs /Vowel + deleted /s// $\left(/ \mathrm{V} / \mathrm{vs} / \mathrm{V}^{\mathrm{s}} /\right)$ in EAS and the present paper aims to analyze other contrasts to ascertain whether EAS speakers can differentiate between word-final /i/ ([i]) and /i/ preceding underlying /-s/ $\left(\left[\mathrm{i}^{\mathrm{s}}\right]\right), / \mathrm{i} /$ preceding underlying /-r/ $\left(\left[\mathrm{i}^{\mathrm{r}}\right]\right)$, and /i/ preceding underlying / $\left.\theta /\left[\mathrm{i}^{\theta}\right]\right)$. Whether /-s/, /-r/, and $/-\theta /$ deletion changes the quality of a preceding /i/ to different degrees has not been 
investigated yet. This, however, has been done for /e/, /o/, and /a/ (Herrero de Haro 2016, 2017a, 2017c) and these findings will be contrasted with the ones for /i/ later on. In the interest of clarity, underlying consonants which are not pronounced by the speakers are written in superscript. It is worth noting that, in Spanish, $/ \mathrm{r} /$ and $/ \mathrm{f} /$ are only contrasted in intervocalic position. These two phones merge in syllable-final position and the phonetic output can vary from tap to trill; this variation is governed by dialectical and stylistic variation (e.g. Blecua Falgueras 2005; Bradley 2014). Following Monroy and Hernández Campoy (2015), I will transcribe the syllable-final rhotic as /r/.

Changes in the phonetic-phonological system of a language tend to affect multiple sounds (Alarcos Llorach 1976:12). However, languages devise new developments to solve any loss of distinction which may arise in a phonemic system (Alarcos Llorach 1976: 122). These ideas motivated the current study in order to investigate whether they are in operation when it comes to $/-\mathrm{s} /, /-\mathrm{r} /$ and $/-\theta /$ deletion.

Many scholars (e.g. Rodríguez-Castellano and Palacio 1948a, 1948; Alarcos Llorach 1983; Martínez Melgar 1994; Jiménez and Lloret 2007; Tejada Giráldez 2012), have posited theories on the phonetic and phonemic systems of EAS. However, the perception of features of EAS by native speakers has not been considered when developing these theories. To my knowledge, García Marcos (1987), O’Neill (2010), and Torreira (2007b) are among the few studies analyzing speech perception in EAS. The perception of underlying /-s/ has been studied in other varieties of Spanish (e.g. Torreira 2007a, 2007b, 2012 and Vida Castro and Villena Ponsoda 2016 for Western Andalusian Spanish; Figueroa 2000 for Puerto Rican Spanish), but I believe that these findings cannot be applied to EAS as, unlike EAS, those varieties of Spanish do not present consistent vowel opening.

Thus, the present paper complements as well as supplements the extensive literature on word-final consonant deletion in Andalusian Spanish and has four objectives: 1) to 
analyze whether $/ \mathrm{i} /$ is subject to vowel opening before deleted /-s/,/-r/, and /- $\theta$ / in EAS; 2 ) to study whether /-s/, /-r/, and /- $\theta /$ deletion causes different changes to the quality of a preceding /i/; 3) to ascertain if EAS speakers from Western Almería can identify whether or not /i/ is followed by an underlying consonant; and, if so, 4) to see whether these speakers can identify in each case whether $/ \mathrm{i} /$ is followed by underlying /-s/, /-r/, or / $-\theta /$.

Speech samples from 24 speakers from El Ejido (Almería) are analyzed acoustically to measure F1 and F2 values for word-final /i/ and for /i/ preceding deleted word-final /s/, /r/, and $/ \theta /$. It is worth remembering that a higher F1 corresponds to more open vowels; a higher F2 corresponds to vowels pronounced further front. Following this, a perception test with native speakers from this area is carried out to ascertain whether EAS speakers can distinguish between $[\mathrm{i}],\left[\mathrm{i}^{\mathrm{s}}\right],\left[\mathrm{i}^{\mathrm{r}}\right]$, and $\left[\mathrm{i}^{\theta}\right]$. Perception studies have also been ignored in EAS (Bishop 2007), and this paper intends to explore the relationship between the vowel contrasts that EAS speakers produce and perceive.

This article is organized into 7 sections. The introduction is in Section 1 and Section 2 includes a review of literature. Section 3 examines the acoustic data obtained for word-final [i], $\left[\mathrm{i}^{\mathrm{s}}\right],\left[\mathrm{i}^{\mathrm{r}}\right]$, and $\left[\mathrm{i}^{\theta}\right]$ and Section 4 analyzes the perception of $[\mathrm{i}],\left[\mathrm{i}^{\mathrm{s}}\right],\left[\mathrm{i}^{\mathrm{r}}\right]$, and $\left[\mathrm{i}^{\theta}\right]$ in EAS speakers. The results from both types of analyses are discussed in Section 5. The conclusions of the study are outlined in Section 6 and the bibliography is presented in Section 7.

\section{Literature review}

Many researchers have quantified EAS vowel opening acoustically (e.g. Martínez Melgar 1994, Sanders 1998, Henriksen 2017), although other authors have argue against this opening (e.g. Martínez Melgar 1986; Carlson 2012). Vowel opening, however, refers to the phonetic realization of vowels, while the phenomenon by which vowel opening carries the semantic function of underlying/-s/ is referred to as "vowel doubling". It is worth noting that 
EAS is the only variety of Spanish where systematic vowel opening has been reported (Henriksen 2017).

Regarding vowel opening, high vowels have been a particular point of discussion, with many researchers debating whether the Spanish high vowels are subject to opening at all. Some authors argue that $/ \mathrm{i} /$ and /u/ open when they precede underlying /-s/ (e.g. Salvador 1957; Peñalver Castillo 2006; Martínez Melgar 1986, 1994), while others say that they do not (e.g. Navarro Tomás 1938, 1939; Sanders 1998; Henriksen 2017).

The phonemic role of vowel opening has also been widely discussed. Some scholars have argued in favour of vowel doubling (e.g. Peñalver Castillo 2006; Herrero de Haro 2016); others argue that vowel opening does not have phonemic value and reject vowel doubling (López Morales 1984; Mondéjar Cumpián 1979; Martínez Melgar 1986). Furthermore, the fact that vowel opening is restricted to word-final position has also been presented by some scholars as evidence that vowel opening cannot be a phonemic feature (e.g. Contreras Jurado 1975, Cerdà Massó 1992). Herrero de Haro and Hajek (in press), however, give examples of word-internal vowel opening preceding debuccalized consonants. Alarcos Llorach (1958, 1983), Contreras Jurado (1975), and Cerdà Massó (1992), on the other hand, propose "vowel system doubling" instead of vowel doubling. Vowel doubling assumes that EAS vowels and their open counterparts are different phonemes, while vowel system doubling assumes that open vowels are affected by a prosodeme; the difference between a vowel and its open counterpart is of a similar nature to the difference between an unstressed and a stressed vowel.

Some research has already been carried out regarding the effects of the deletion of different consonants on preceding vowels but this has been very limited. Wulff (1889) described different effects of consonant deletion on previous vowels (e.g. different degrees of vowel lengthening depending on which underlying consonant followed each vowel). 
Likewise, Alvar et al. (1973: maps 1626 and 1629) noticed how deleted /-s/ and /- $\theta /$ are not neutralized word-finally across Andalusia; vowel quality seemed to differ depending on whether a vowel is followed by underlying /-s/ or $/-\theta /$. Furthermore, studies on EAS vowels have been carried out perceptually and no acoustic analyses have been performed on such phenomena.

At this point, it is worth reviewing the results obtained in previous studies for the F1 and F2 of EAS and Castilian Spanish (henceforth $C S$ ) /i/ before analyzing how /-s/, /-r/, and $/-\theta /$ deletion changes the quality of /i/ in Western Almería; unlike EAS, CS is characterized by maintaining all consonants in coda. All values in these tables have been rounded to the nearest whole number.

Table 1. Formant values for Castilian and EAS [i] in open syllable and for EAS $\left[\mathrm{i}^{\mathrm{s}}\right]$.

\begin{tabular}{|c|c|c|c|}
\hline Study & Type of /i/ & F1 & F2 \\
\hline Alarcos Llorach (1976) & Castilian /i/ & 400 & 2000 \\
\hline Quilis (1981) & Castilian /i/ & 240 & 2450 \\
\hline Quilis and Esgueva (1983) & Castilian /i/ Male & 268 & 2342 \\
\hline \multirow[t]{2}{*}{ Quilis and Esgueva (1983) } & \multirow[t]{2}{*}{ Castilian /i/ } & 265 (male) & 2318 (male) \\
\hline & & 241 (female) & 2835 (female) \\
\hline Martínez Celdrán (1984) & Castilian /i/ & 346 & 2198 \\
\hline \multirow[t]{2}{*}{ Martínez Celdrán (1995) } & \multirow{2}{*}{$\begin{array}{l}\text { Castilian /i/ in 20-30-year-old } \\
\text { speakers }\end{array}$} & 313 (male) & 2200 (male) \\
\hline & & 369 (female) & 2685 (female) \\
\hline \multicolumn{2}{|l|}{ Mean value } & 305 & 2379 \\
\hline Martínez Melgar (1986) & EAS /i/ & 382 & 2050 \\
\hline Martínez Melgar (1994) & EAS /i/ & 389 & 2166 \\
\hline Sanders (1994) & EAS /i/ & 341 & 2245 \\
\hline Sanders (1998) & Pretonic EAS /i/ & 353 & 2234 \\
\hline Sanders (1998) & Tonic EAS /i/ & 330 & 2257 \\
\hline Corbin (2006) & EAS /i/ & 368 & 2600 \\
\hline \multicolumn{2}{|l|}{ Mean value } & 361 & 2259 \\
\hline Martínez Melgar (1986) & EAS /i/ preceding deleted /-s/ & 382 & 2005 \\
\hline Martínez Melgar (1994) & EAS /i/ preceding deleted /-s/ & 411 & 2073 \\
\hline Sanders (1994) & EAS /i/ preceding deleted /-s/ & 349 & 2215 \\
\hline Sanders (1998) & $\begin{array}{l}\text { Pre-tonic EAS /i/ preceding } \\
\text { deleted } / \text {-s/ }\end{array}$ & 354 & 2217 \\
\hline Sanders (1998) & $\begin{array}{l}\text { Tonic EAS /i/ preceding deleted } \\
\text { /-s/ }\end{array}$ & 343 & 2213 \\
\hline Corbin (2006) & EAS /i/ preceding deleted /-s/ & 429 & 2460 \\
\hline \multicolumn{2}{|l|}{ Mean value } & 378 & 2197 \\
\hline
\end{tabular}


These reported F1 and F2 values suggest that EAS /i/ is more open and back than its CS counterpart. This shows a tendency of EAS /i/ towards centralization if compared with CS /i/. Herrero de Haro $(2016,2017$ a) shows a similar tendency towards centralization for EAS /e/ and /o/ when compared to CS vowels. This is in line with Corbin's (2006) findings. This tendency towards centralization is what might have prompted some scholars to refer to the distinction between word-final EAS vowels and EAS vowels preceding underlying /-s/ as word not affected by prosodeme of openness vs affected word (Contreras Jurado 1975) or as open vs non-open vowel distinction (Martínez Melgar 1986).

As we can see in Table 1, Martínez Melgar (1986) reports exactly the same value for the F1 of [i] as for $\left[\mathrm{i}^{\mathrm{s}}\right]$; however, she reports backing of /i/ preceding deleted /-s/. Likewise, Martínez Melgar (1994), Sanders (1994, 1998), and Corbin (2006) report opening and backing of /i/ before underlying /-s/, although Sanders (1994) reports only a slight opening of /i/ and Sanders (1998) reports only a very slight opening of pre-tonic /i/. As explained in Herrero de Haro (2016, 2017a), these authors also present opening of /e/ and /o/ preceding underlying /-s/. Corbin (2006), however, measured F1 and F2 values for three different realizations of /i/: [is] (F1 393, F2 2560), [ih] (F1 415, F2 2540), and [is] (F1 424, F2 2540). As Corbin (2006) reported for /e/ and /o/, /i/ is more open when it precedes /-s/ deletion than when it precedes $[\mathrm{s}]$; the degree of opening of $/ \mathrm{i} /$ preceding $[\mathrm{h}]$ is between that found in $\left[\mathrm{i}^{\mathrm{s}}\right]$ and in [is]. As one reviewer pointed out, there is a 20-year gap between some of the studies mentioned in Table 1; calculating the mean for the F1 and F2 is useful to understand variability between $[\mathrm{i}]$ and $\left[\mathrm{i}^{\mathrm{s}}\right]$ but it must be noted that a linguistic change could have taken place in those two decades. 


\section{Acoustic study}

\subsection{Data collection: Acoustic study}

The present study analyzes the speech of El Ejido (a town in Western Almería which is 36km west from the border with Granada province). The researcher visited his native town of El Ejido and interviewed speakers from the area. The interviewees were friends and family of the researcher, students from local primary and secondary schools, and general members of the public who were approached in parks and in the street.

Table 2. Age and gender of the speakers recorded.

\begin{tabular}{|c|c|c|c|c|c|}
\hline Gender & $\begin{array}{c}\text { Number of } \\
\text { speakers }\end{array}$ & $\begin{array}{c}\text { Speakers per } \\
\text { age group }\end{array}$ & Age range & Mean age & Stan Dev \\
\hline Male & 15 & $4:<20$ & $12-78$ & 32 years 6 months & \\
& & $9: 20-50$ & & & \\
& & $2:>50$ & & & \\
\hline Female & 9 & $1:<20$ & $17-78$ & 42 years and 4 months & \\
& & $5: 20-50$ & & & \\
& & $3:>50$ & & & \\
\hline
\end{tabular}

All the speakers recorded for this study were native to El Ejido and their speech displayed the typical characteristics of EAS (e.g. deletion of coda consonants, vowel opening before underlying consonants). None of the 24 speakers recorded for this study presented either seseo (pronouncing / $\theta /$ as [s]: cinco ['sinko] 'five') or ceceo (pronouncing /s/ as [0]: sí [ $\theta \mathrm{i}]$ 'yes'); that is, they all differentiated /s/ as in casa ['kasa] 'house' from $/ \theta /$ as in caza ['kaقa] 'hunt'. If we consider that any changes experienced by a preceding vowel once /s/ or $/ \theta /$ are deleted could be due to underlying coarticulation, then it is important to consider whether a speaker would have $[\mathrm{s}]$ or $[\theta]$ as the deleted output; it must be noted that, for all the participants analyzed in the present paper, the deleted consonant in $/ \mathrm{s} /$ is $[\mathrm{s}]$ and in $/ \theta /$ is $[\theta]$. In all the tokens analyzed in the present paper, the etimological underlying word-final 
consonant reemerged in the plural form; the plural of lápiz ['lapi] 'pencil' was lápices ['lạpịe] 'pencils', not *lápis as in Villena Ponsoda (1987: 20 -23).

Regan (2017) describes how ceceo is currently demerging in some parts of Western Andalusia in favour of the distinction between $/ \mathrm{s} /$ and $/ \theta /$, but I believe that this process is considerably more advanced in some parts of Eastern Andalusia. For example, Navarro Tomás et al. (1933) reported that younger speakers distinguished $/ \mathrm{s} /$ from $/ \theta /$ in Western Almería, the area under investigation in the present paper. Nevertheless, I acknowledge that distinguishing $/ \mathrm{s} /$ and $/ \theta /$ is not the norm across Eastern Andalusia (e.g. Peñalver Castillo (2006) found seseo in Cabra (Córdoba)). Further details on the characteristics of EAS can be found in Villena Ponsoda (2000, 2008), Valeš (2014), Moya Corral (2010), Jiménez Fernández (1999), and Herrero de Haro and Hajek (in press).

Given that vowel opening has been reported throughout Eastern Andalusia (e.g. Alvar et al. 1973; Herrero de Haro 2017b; Henriksen 2017), it is plausible that the findings reported in this paper apply to EAS as a whole.

The interviews had three parts whenever possible: 1) an informal conversation about everyday topics (e.g. holidays, work); 2) naming objects from some photos; 3) reading words and phrases which contained combinations of sounds which are rare in Spanish (e.g. wordfinal $/ \mathrm{i} \theta /$ ). It is worth noting that the informal topic of the conversation, together with the native EAS accent of the interviewer, made the participants feel at ease when using their vernacular geolect, as opposed to feeling anxious about being observed by someone with a more normative regional language variety; the importance of using a local speaker to elicit natural forms of speech is highlighted in Martínez Melgar (1986) and Henriksen and Willis (2010). The data analyzed in this study come from a larger investigation on EAS vowels and the results for /e/, /o/, /a/, and /u/ are presented in Herrero de Haro (2016, 2017a, 2017c, 
under review), respectively. The speech samples were recorded using a Zoom H2n digital recorder and analyzed on Praat (Boersma and Weenink 2016).

Following the suggestions of some researchers (e.g. Sanders 1998; Torreira 2012), only recordings obtained during free conversations and when naming objects were analyzed in the end for the present study. This was done in order to focus on more natural forms of speech. The table below shows the number of tokens analyzed for each realization of $/ \mathrm{i} /$.

Table 3. Tokens of $[\mathrm{i}],\left[\mathrm{i}^{\mathrm{s}}\right],\left[\mathrm{i}^{\mathrm{r}}\right]$, and $\left[\mathrm{i}^{\mathrm{\theta}}\right]$ analyzed.

\begin{tabular}{|c|c|c|c|c|}
\hline$[\mathbf{i}]$ & {$\left[\mathbf{i}^{\mathbf{s}}\right]$} & {$\left[\mathbf{i}^{\mathbf{r}}\right]$} & {$\left[\mathbf{i}^{\boldsymbol{\theta}}\right]$} & Total \\
\hline 143 & 80 & 90 & 70 & $\mathbf{3 8 3}$ \\
\hline
\end{tabular}

These vowels were analyzed in word-final position. The F1 and F2 of /is/, /ir/, and /i $\theta$ / were analyzed only when the final consonant had been totally deleted and pronounced as $\left[\mathrm{i}^{\mathrm{s}}\right]$, $\left[\mathrm{i}^{\mathrm{r}}\right]$, and $\left[\mathrm{i}^{\theta}\right]$ (i.e. the author could not hear the consonant or an aspiration after the vowel and no hangover of the underlying consonant could be found in the spectrogram). No realization of /i/ was analyzed if this was preceded or followed by another vowel (e.g. ir $a$ [i ${ }^{\mathrm{r}}$ a] 'to go to'; coméis [ko'mẹi] 'you informal pl. eat'). This was done in order to avoid analyzing vowels which might have been affected by coarticulation; this type of coarticulation would have made it difficult to analyze the effects of $/ \mathrm{s} /, / \mathrm{r} /$, or $/ \theta /$ deletion on $/ \mathrm{i} /$.

The recordings were played on Praat (Boersma and Weenink 2016) and when [i], [is], $\left[i^{r}\right]$, or $\left[i^{\theta}\right]$ were identified word-finally, the recording was paused and the spectrogram of each relevant vowel analyzed. The F1 and F2 of each vowel were only analyzed during the stable section closest to the peak of intensity to avoid measuring parts of the vowel affected by coarticulation. The mean values of F1 and F2 were taken from the stable section of the vowel. All F1 and F2 measurements were taken manually and no script was used. After careful consideration, it was decided not to normalize formants to allow for a like-for-like comparison with the extensive research already undertaken in EAS vowels; a detailed review of literature of EAS vowels can be found in Herrero de Haro (2017b). 


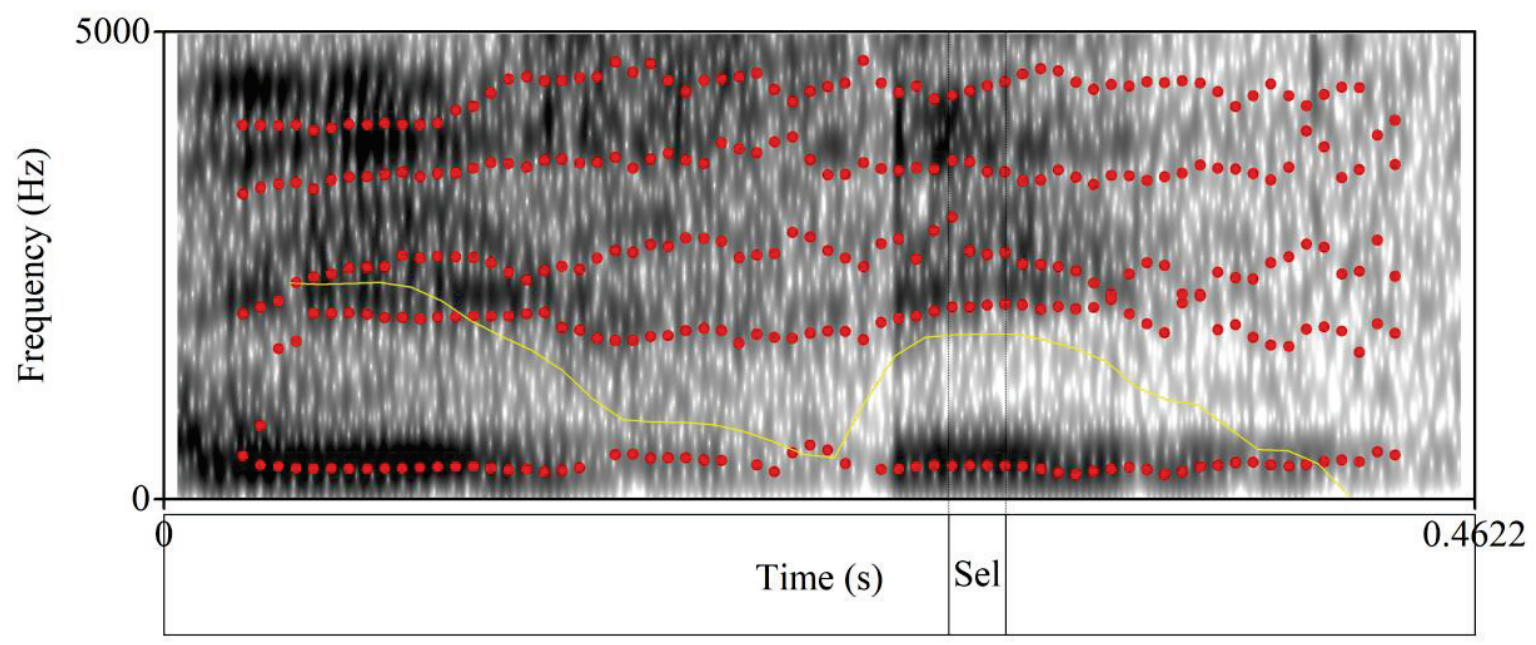

Figure 1. Sample of analyzed portion of [i $\left.\mathrm{i}^{\mathrm{s}}\right]$ in bicis ['bi $\left.\theta \mathrm{i}^{\mathrm{s}}\right]$ 'bicycles'.

All formant values were rounded to the nearest whole number (e.g. 372.8 became 373 and 2234.2 became 2234). This was also done when reporting formant values from other studies. Each measurement was grouped under the category $[\mathrm{i}],\left[\mathrm{i}^{\mathrm{i}}\right],\left[\mathrm{i}^{\mathrm{r}}\right]$, or $\left[\mathrm{i}^{\theta}\right]$ on an Excel spreadsheet and the mean and standard deviation were calculated for the F1 and F2 of each of the four realizations of $/ \mathrm{i} /$.

\subsection{Acoustic analysis of EAS/i/}

EAS scholars have focused on studying the effects of /s/ deletion, ignoring other consonants which are also deleted syllable-finally (Gerfen and Hall 2001). In contrast, the present study explores a more complex reality of consonant deletion in EAS and its effects on preceding /i/. The following table summarizes the values obtained in the present study for EAS $[\mathrm{i}],\left[\mathrm{i}^{\mathrm{s}}\right],\left[\mathrm{i}^{\mathrm{r}}\right]$, and $\left[i^{\theta}\right]$ word-finally.

Table 4. F1 and F2 values for word-final $[\mathrm{i}],\left[\mathrm{i}^{\mathrm{s}}\right],\left[\mathrm{i}^{\mathrm{r}}\right]$, and $\left[\mathrm{i}^{\theta}\right]$ in EAS.

\begin{tabular}{|c|c|c|c|c|c|}
\hline Vowel & F1 & F2 & Stan Dev F1 & Stan Dev F2 & Tokens \\
\hline$[\mathbf{i}]$ & 369 & 2154 & 47.08 & 221.12 & 143 \\
\hline$\left[\mathbf{i}^{\mathbf{s}}\right]$ & 402 & 2218 & 43.69 & 258.98 & 80 \\
\hline$\left[\mathbf{i}^{\mathbf{r}}\right]$ & 408 & 2186 & 44.32 & 237.54 & 90 \\
\hline$\left[\mathbf{i}^{\theta}\right]$ & 393 & 2265 & 43.05 & 293.98 & 70 \\
\hline
\end{tabular}


The characteristics of these realizations of /i/ are easier to appreciate in the following graph.

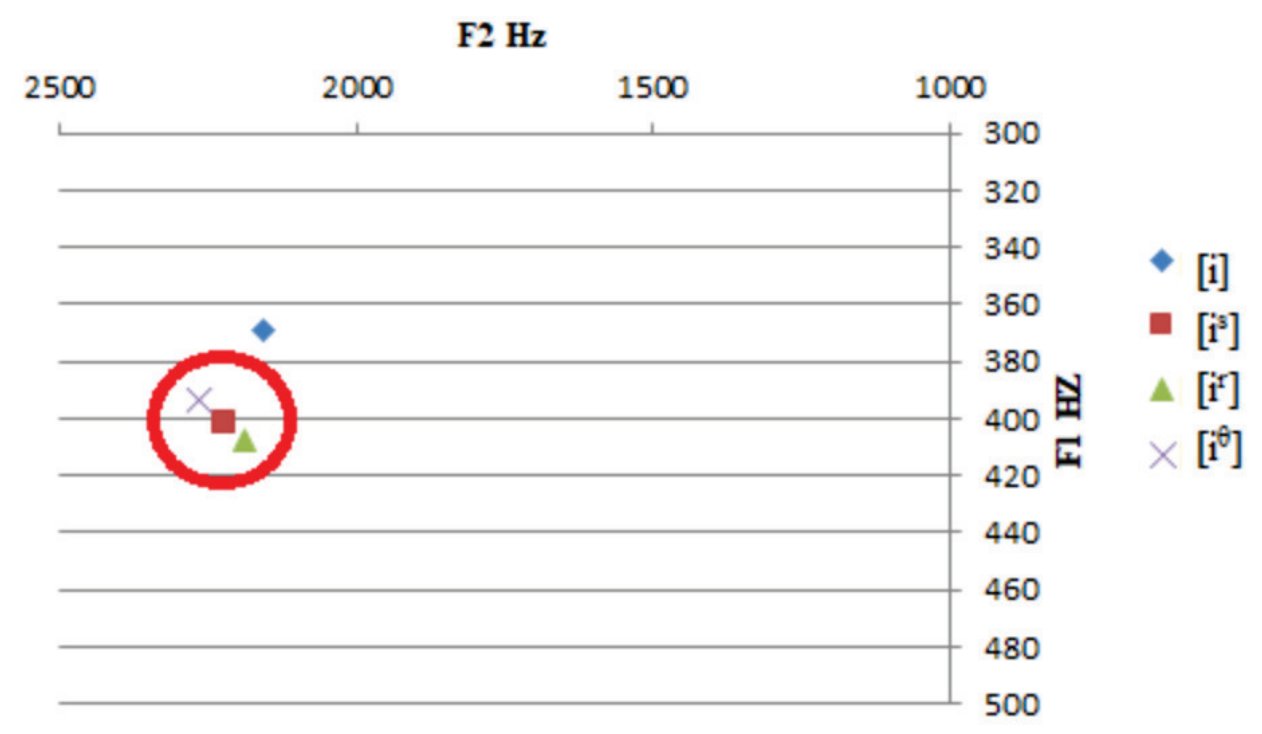

Figure 2. Average F1 and F2 values for EAS $[\mathrm{i}],\left[\mathrm{i}^{\mathrm{s}}\right],\left[\mathrm{i}^{\mathrm{r}}\right]$, and $\left[\mathrm{i}^{\theta}\right]$ word-finally.

The circle marking the acoustic space of $\left[\mathrm{i}^{\mathrm{s}}\right],\left[\mathrm{i}^{\mathrm{r}}\right]$, and $\left[\mathrm{i}^{\theta}\right]$ has no statistical value.

The values reported in Table 4 for $/ \mathbf{i} /$ are much closer to those reported for EAS than for CS in Table 1. Regarding F1, the values reported in the present study for / $\mathrm{i} /$ are in line with those reported by Martínez Melgar (1986, 1994), Sanders (1994, 1998), and Corbin (2006) for EAS, and slightly higher than those reported for CS. Alarcos Llorach (1976), however, reports a higher value for F1 in CS /i/ than the value obtained in the present study.

The data from Table 4 suggest that / $\mathbf{i} /$ is more open and pronounced further front when it precedes deleted /s/ (F1 402, F2 2218) than when it appears word-finally (F1 369, F2 2154). This means that /i/ opens when it precedes underlying/-s/, which contradicts what has been posited by some researchers (e.g. Navarro Tomás 1938, 1939; Zubizarreta 1979).

The values reported for word-final EAS $\left[\mathrm{i}^{\mathrm{s}}\right]$ in Table 4 are slightly higher than those reported in Table 1, especially when it comes to F1. The values obtained in the present study 
present a slightly higher F1 value in word-final EAS $\left[i^{\mathrm{s}}\right](\mathrm{F} 1$ 402) than the mean value obtained from previous studies (Table 1 - F1 378). Martínez Melgar (1986) and Sanders (1994, 1998) posit a lower value for EAS $\left[\mathrm{i}^{\mathrm{s}}\right]$ word-finally than the one obtained in the present paper; Martínez Melgar (1986) and Corbin (2006) propose a higher value. There is no major discrepancy between previous results for EAS $\left[i^{\mathrm{s}}\right]$ word-finally and the results obtained in the current study. Results for F2, however, are more similar. The results presented in Table 4 are virtually the same as those reported in Sanders $(1994,1998)$, slightly higher than the ones reported in Martínez Melgar (1986, 1994), and considerably lower than the results from Corbin (2006).

The present analysis shows that /i/ is more open when it precedes /-s/ deletion. This is in line with the results obtained for /e/, /o/, and /a/ in Herrero de Haro (2016, 2017a, 2017c). This opening of /i/ supports the results presented in Alvar (1955), Salvador (1957, 1977), Mondéjar Cumpián (1979), Martínez Melgar (1994), Sanders (1994), and Corbin (2006). Moreover, López Morales (1984) posited that vowel opening was a phonetic feature with no phonemic value and Zubizarreta (1979) theorized that /i/ and /u/ underwent phonetic but not phonemic laxing. These claims, however, have not been tested and the perception test discussed in Section 4 will investigate this.

Word-final EAS $\left[\mathrm{i}^{\mathrm{r}}\right]$ has not been analyzed acoustically in previous studies; thus, it is not possible to compare the values from Table 4 with previous data. However, Navarro Tomás $(1938,1939)$ carried out an impressionistic study and posited that vowels open less when they precede /-r/ deletion than when they precede /-s/ deletion; Jiménez and Lloret (2007) also support this. Alvar et al. (1973: map 1624) carried out an impressionistic analysis of the word decir 'to say' and their results show opening of /i/ preceding an underlying $/ \mathrm{r} /$.

The data from Table 4 show that /i/ has a higher F1 when it precedes /-r/ deletion than when it precedes /-s/ deletion, which suggests that the deletion of /-s/ and /-r/ causes different 
changes to the $\mathrm{F} 1$ of a preceding $/ \mathrm{i} /$. EAS word-final $\left[\mathrm{i}^{\mathrm{r}}\right]$ is more fronted than [i] but less than $\left[i^{\mathrm{s}}\right]$, which suggests that $/-\mathrm{s} /$ and /-r/ deletion also have an effect on the F2 of a preceding /i/. This has never been posited before and the perception test discussed in Section 4 will clarify whether EAS speakers can differentiate between $\left[\mathrm{i}^{\mathrm{s}}\right]$ and $\left[\mathrm{i}^{\mathrm{r}}\right]$.

Table 4 shows that $\left[i^{\theta}\right]$ is more open than $[\mathrm{i}]$ but less open than $\left[\mathrm{i}^{\mathrm{s}}\right]$ and $\left[\mathrm{i}^{\mathrm{r}}\right]$, showing that word-final $[\theta]$ deletion opens a preceding /i/ to a lesser degree than /-s/ or /-r/ deletion. This is also the case for EAS /a/ (Herrero de Haro 2017c). F2 values show that $\left[\mathrm{i}^{\theta}\right]$ is pronounced further front than $[\mathrm{i}],\left[\mathrm{i}^{\mathrm{s}}\right]$, and $\left[\mathrm{i}^{\mathrm{r}}\right]$.

To my knowledge, there have been no previous analyses of /i/ preceding underlying $/-\theta /$, which means that the values obtained in the present study cannot be compared to previous findings from other researchers. Taking into account the data presented in Table 4, it seems that the quality of /i/ varies depending on whether this vowel appears word-finally or before an underlying /-s/, /-r/, or /- $\theta /$. This seems to indicate that the deletion of word-final $/ \mathrm{s} /, / \mathrm{r} /$, and $/ \theta /$ modifies the quality of a previous $/ \mathrm{i} /$ in different degrees. This was also the case for /e/, /o/, and /a/ in Herrero de Haro (2016, 2017a, 2017c), respectively, where F1 and F2 values showed that the quality of each of these three vowels varied depending on whether they appear in word-final position or before an underlying /-s/, /-r/, or /- $\theta /$.

As we can see in Table 4 and in Figure 2, F1 values for /i/ preceding underlying /-s/, /-r/, and /- $\theta$ / are higher than for word-final /i/. Regarding F2, the vowel /i/ is slightly fronted when it precedes /-r/ deletion, $\left[\mathrm{i}^{\mathrm{s}}\right]$ is pronounced further front than $\left[\mathrm{i}^{\mathrm{r}}\right]$ and, finally, $\left[\mathrm{i}^{\theta}\right]$ shows the highest degree of fronting.

\subsection{Statistical analysis: Acoustic study}

A series of statistical tests were run on SPSS in order to explore whether the different F1 and F2 values obtained for the 383 tokens of /i/ were statistically significant. The baseline p-value for determining statistical significance was 0.5. A one-way ANOVA was performed 
to find out whether the differences of quality between $[\mathrm{i}],\left[\mathrm{i}^{\mathrm{s}}\right],\left[\mathrm{i}^{\mathrm{r}}\right]$, and $\left[\mathrm{i}^{\theta}\right]$ were statistically significant. A one-way ANOVA can identify whether the difference for F1 and F2 values of $[i],\left[i^{\mathrm{s}}\right],\left[\mathrm{i}^{\mathrm{r}}\right]$, and $\left[\mathrm{i}^{\theta}\right]$ are statistically significant; however, it cannot determine which differences in F1 or F2 are statistically significant. In order to examine this, a Tukey post hoc test was performed after the one-way ANOVA.

The one-way ANOVA found that the effect of consonant deletion on the F1 of [i], [is], $\left[\mathrm{i}^{\mathrm{r}}\right]$, and $\left[\mathrm{i}^{\theta}\right]$ was significant $(\mathrm{F}(3,379)=16.657$, p-value $=.000)$; the effect of consonant deletion on the $\mathrm{F} 2$ values of $[\mathrm{i}],\left[\mathrm{i}^{\mathrm{s}}\right],\left[\mathrm{i}^{\mathrm{r}}\right]$, and $\left[\mathrm{i}^{\theta}\right]$ was also significant $(\mathrm{F}(3,379)=3.431, p$ value $=.017)$.

A Tukey post hoc test was performed to identify which differences in the F1 and F2 of $[\mathrm{i}],\left[\mathrm{i}^{\mathrm{s}}\right],\left[\mathrm{i}^{\mathrm{r}}\right]$, and $\left[\mathrm{i}^{\theta}\right]$ were statistically significant. In the interest of clarity, $p$-value results from the cross comparison between the F1 and F2 of $[i],\left[i^{\mathrm{s}}\right],\left[i^{\mathrm{r}}\right]$, and $\left[i^{\theta}\right]$ have been included in Tables 5 and 6.

Table 5. $p$-value for differences between the F1 of EAS $[\mathrm{i}],\left[\mathrm{i}^{\mathrm{i}}\right],\left[\mathrm{i}^{\mathrm{r}}\right]$, and $\left[\mathrm{i}^{\theta}\right]$ word-finally.

\begin{tabular}{l|c|c|c|c|c|}
\hline $\mathbf{F} 1$ & {$[\mathbf{i}]$} & {$\left[\mathbf{i}^{\mathbf{s}}\right]$} & {$\left[\mathbf{i}^{\mathbf{r}}\right]$} & {$\left[\mathbf{i}^{\mathbf{\theta}}\right]$} \\
\hline$[\mathbf{i}]$ & & $\begin{array}{c}.000 \\
*\end{array}$ & $\begin{array}{c}.000 \\
*\end{array}$ & $\begin{array}{c}.003 \\
*\end{array}$ \\
\hline $\left.\mathbf{i}^{\mathbf{i}}\right]$ & $\begin{array}{c}.000 \\
*\end{array}$ & & .850 & .565 \\
\hline$\left[\mathbf{i}^{\mathbf{r}}\right]$ & $\begin{array}{c}.000 \\
*\end{array}$ & .850 & & .151 \\
\hline$\left[^{\mathbf{\theta}}\right]$ & $\begin{array}{c}.003 \\
*\end{array}$ & .565 & .151 & \\
* indicates differences which are statistically significant $(p$-value $<0.5)$.
\end{tabular}

As we can see in Table 5, the F1 differences between the four realizations of /i/ which are statistically significant are $[\mathrm{i}]-\left[\mathrm{i}^{\mathrm{s}}\right](p$-value $=.000),[\mathrm{i}]-\left[\mathrm{i}^{\mathrm{r}}\right](p$-value $=.000)$, and $[\mathrm{i}]-$ $\left[\mathrm{i}^{\theta}\right](p$-value $=.003)$; the differences between the pairs $\left[\mathrm{i}^{\mathrm{s}}\right]-\left[\mathrm{i}^{\mathrm{r}}\right],\left[\mathrm{i}^{\mathrm{s}}\right]-\left[\mathrm{i}^{\theta}\right]$, and $\left[\mathrm{i}^{\mathrm{r}}\right]-\left[\mathrm{i}^{\theta}\right]$ are not statistically significant and show that $\left[i^{\mathrm{s}}\right],\left[\mathrm{i}^{\mathrm{r}}\right]$, and $\left[\mathrm{i}^{\theta}\right]$ pattern together but differ from $[\mathrm{i}]$. 
Table 6. $p$-value for differences between the F2 of word-final $[\mathrm{i}],\left[\mathrm{i}^{\mathrm{s}}\right],\left[\mathrm{i}^{\mathrm{r}}\right]$, and $\left[\mathrm{i}^{\theta}\right]$ in EAS.

\begin{tabular}{|c|c|c|c|c|}
\hline $\mathbf{F 2}$ & {$[\mathbf{i}]$} & {$\left[\mathbf{i}^{\mathbf{s}}\right]$} & {$\left[\mathbf{i}^{\mathrm{r}}\right]$} & $\left.\mathbf{i}^{\mathbf{\theta}}\right]$ \\
\hline$[\mathbf{i}]$ & & .262 & .785 & $\begin{array}{c}.012 \\
*\end{array}$ \\
\hline$\left[\mathbf{i}^{\mathbf{s}}\right]$ & .262 & & .835 & .641 \\
\hline$\left[\mathbf{i}^{\mathrm{r}}\right]$ & .785 & .835 & & .182 \\
\hline$\left[\mathbf{i}^{\boldsymbol{\theta}}\right]$ & $\begin{array}{c}.012 \\
*\end{array}$ & .641 & .182 & \\
\hline
\end{tabular}

* indicates differences which are statistically significant $(p$-value $<0.5)$.

The results for the $\mathrm{F} 2$ of $[\mathrm{i}],\left[\mathrm{i}^{\mathrm{s}}\right],\left[\mathrm{i}^{\mathrm{r}}\right]$, and $\left[\mathrm{i}^{\theta}\right]$ are quite different to the results obtained for F1. According to this analysis, the variation of F2 is only statistically different between [i] and $\left[i^{\theta}\right]$.

Taking into account the results from Tables 5 and 6 , out of the six possible pairs which could be contrasted $\left([\mathrm{i}]-\left[\mathrm{i}^{\mathrm{s}}\right],[\mathrm{i}]-\left[\mathrm{i}^{\mathrm{r}}\right],[\mathrm{i}]-\left[\mathrm{i}^{\theta}\right],\left[\mathrm{i}^{\mathrm{s}}\right]-\left[\mathrm{i}^{\mathrm{r}}\right],\left[\mathrm{i}^{\mathrm{s}}\right]-\left[\mathrm{i}^{\theta}\right]\right.$, and $\left.\left[\mathrm{i}^{\mathrm{r}}\right]-\left[\mathrm{i}^{\theta}\right]\right)$, only the contrasts $[\mathrm{i}]-\left[\mathrm{i}^{\mathrm{s}}\right],[\mathrm{i}]-\left[\mathrm{i}^{\mathrm{r}}\right]$, and $[\mathrm{i}]-\left[\mathrm{i}^{\theta}\right]$ have a difference which is statistically significant. These results contrast with what was reported for /e/, /o/ and /a/ in Herrero de Haro (2016, 2017a, 2017c); the deletion of /-s/, /-r/, and /- $\theta /$ changes the quality of a preceding /i/ in different degrees but these differences are not strong enough to consider $\left[\mathrm{i}^{\mathrm{s}}\right],\left[\mathrm{i}^{\mathrm{r}}\right]$, and $\left[\mathrm{i}^{\theta}\right]$ as three different allophones of $/ \mathrm{i} /$. As such, we can confirm that the deletion of $/ \mathrm{s} /, / \mathrm{r} /$, and $/ \theta /$ word-finally in EAS creates a system of only two allophones: word-final /i/ ([i]) and /i/ preceding underlying $/ \mathrm{s} /, / \mathrm{r} /$, and $/ \theta /\left(\left[\mathrm{i}^{\mathrm{s} / \mathrm{r} / \theta}\right]\right)$. This contrasts with the findings presented in Herrero de Haro $(2016,2017 \mathrm{a}, 2017 \mathrm{c})$, where /e/, /o/, and /a/ were found to have four different realization depending on whether they were word-finally or before an underlying word-final /s/, /r/, or $/ \theta /$.

Although the differences between $\left[\mathrm{i}^{\mathrm{s}}\right],\left[\mathrm{i}^{\mathrm{r}}\right]$, and $\left[\mathrm{i}^{\theta}\right]$ are not statistically significant, the perception test analyzed in Section 4 will establish whether EAS speakers can differentiate between $[\mathrm{i}],\left[\mathrm{i}^{\mathrm{s}}\right],\left[\mathrm{i}^{\mathrm{r}}\right]$, and $\left[\mathrm{i}^{\theta}\right]$. 
The pairs $[\mathrm{i}]-\left[\mathrm{i}^{\mathrm{s}}\right],[\mathrm{i}]-\left[\mathrm{i}^{\mathrm{r}}\right]$, and $[\mathrm{i}]-\left[\mathrm{i}^{\theta}\right]$ present formants whose differences are statistically significant and, as such, the correct identification of these contrasts could be attributed to vowel height and/or fronting. However, differentiating between contrasts whose F1 and F2 values are not statistically significant would indicate that there are other perceptual clues at play other than vowel height and fronting.

It is worth remembering that in CS a vowel can (partly) assimilate to the place of articulation of a following consonant in a closed syllable. The changes identified in the F1 and $\mathrm{F} 2$ of $/ \mathrm{i} /$ in the present paper could be due to what we could call underlying coarticulation; this could account for the partial assimilation of a vowel to the place of articulation of an underlying following consonant. This, however, is a mere hypothesis and, although this could explain F1 and F2 movements on EAS vowels depending on what consonant has been deleted, it does need further investigation, which falls outside the remit of the present paper.

\section{Perception experiment}

\subsection{Data collection: Perception study}

The researcher recorded himself saying $i$, is, ir and $i z$ multiple times in his EAS accent, pronouncing these items as $[\mathrm{i}],\left[\mathrm{i}^{\mathrm{i}}\right],\left[\mathrm{i}^{\mathrm{r}}\right]$, and $\left[\mathrm{i}^{\theta}\right]$. These vowels were uttered in isolation to avoid any perceptual cues that could arise from coarticulatory processes. Two examples per realization were chosen, opting for samples with stereotypical features of EAS accent (e.g. F1 and F2 values similar to the ones identified in Table 4). These vowels were copied onto an audio track using Audacity (Audacity Team 2014) and then numbers read in a normative CS accent by the researcher were added before each token. This was done to enable participants to know which question they were answering at all times (e.g. tres $\left[\mathrm{i}^{\mathrm{i}}\right]$ 'three $\left[\mathrm{i}^{\mathrm{s}}\right]$ '; siete $[\mathrm{i}]$ 'seven [i]'). The tokens were randomized and each participant heard two items of each realization (i.e. two $[\mathrm{i}]$, two $\left[\mathrm{i}^{\mathrm{s}}\right]$, two $\left[\mathrm{i}^{\mathrm{r}}\right]$, and two $\left[\mathrm{i}^{\theta}\right]$ ); this explains why the number of 
answers for each realization is twice the amount of participants. The forced-choice test which the participants had to complete is included in the Appendix. In this test, each person had to listen to the stimulus and match each realization of /i/ they heard with $[\mathrm{i}],\left[\mathrm{i}^{\mathrm{s}}\right],\left[\mathrm{i}^{\mathrm{r}}\right]$, or $\left[\mathrm{i}^{\theta}\right]$.
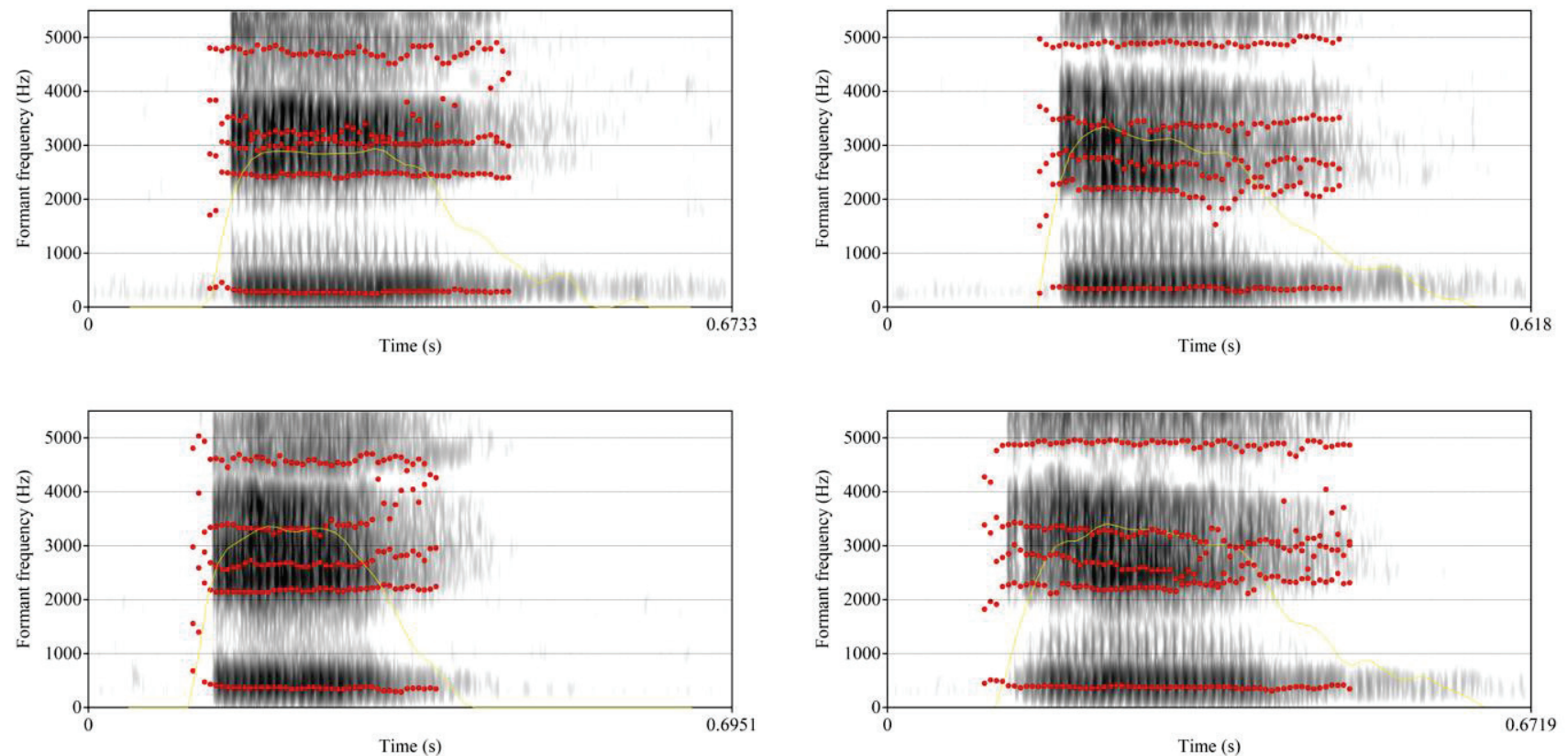

Figure 3. Spectrogram of one example of $[i],\left[i^{\mathrm{s}}\right],\left[\mathrm{i}^{\mathrm{r}}\right]$, and $\left[\mathrm{i}^{\theta}\right]$ used in the perception experiment.

Ethic clearance was obtained from the author's institution, from the Office of Education in Almería, and from each participating school. The experiment was carried out in five secondary schools in Western Almería (two in El Ejido, two in Adra, and one in Balerma) and in one primary school in El Ejido. To ensure that all participants were native speakers of EAS, answers were discarded from respondents who had not lived in Western Almería since at least four years of age. There were 18 participants from the primary school and 121 from the secondary schools. Out of the 139 participants, 72 were males and 65 females; the youngest was 11 years of age and the oldest was 17 (mean: 14.1; standard deviation: 1.43$)$.

Each secondary school participant completed the task using an individual MP3 player with earphones. The primary school group completed the test listening to the stimulus 
through the interactive board's speakers; however, as explained in Section 4.2, listening to the stimulus on the speakers did not affect the rate of identification of the primary school group in a negative way.

The researcher asked the respondents not to guess, but to leave answers blank when unsure. The number of answers collected was 1112 (278 for each of the four realizations of /i/: $[\mathrm{i}],\left[\mathrm{i}^{\mathrm{s}}\right],\left[\mathrm{i}^{\mathrm{r}}\right]$, and $\left.\left[\mathrm{i}^{\theta}\right]\right)$. Out of the 1112 answers obtained, 32 were blank answers $(2.88 \%): 2$ answers were left blank for $[\mathrm{i}](0.72 \%) ; 13$ for $\left[\mathrm{i}^{\mathrm{s}}\right](4.68 \%) ; 11$ for $\left[\mathrm{i}^{\mathrm{r}}\right](3.96 \%)$; and 6 for $\left[\mathrm{i}^{\theta}\right]$ $(2.16 \%)$. It is worth noting that even phonemes played in full words are not always identified with $100 \%$ accuracy by native speakers Herrero de Haro (2016). Leaving blank answers, as opposed to guessing the right answers, should be taken as an indication of the reliability of the respondents.

\subsection{Perception test: $[i]$ vs $\left[i^{s}\right]$ vs $\left[i^{r}\right]$ vs $\left[i^{\theta}\right]$}

The participants listened to audio recordings and identified whether each vowel played was $[i],\left[i^{\mathrm{s}}\right],\left[\mathrm{i}^{\mathrm{r}}\right]$, or $\left[\mathrm{i}^{\theta}\right]$. They entered their responses on an individual answer sheet (Appendix).

The results from the perception test are summarized below. The description all possible answers-blank answers means the total number of possible correct answers for the completed responses (e.g. if 10 student completed the test and five submitted blank answers, the number of correct-blank answers would be five).

These results have been first divided by the method in which each cohort of students listened to the audio and then combined in a table with overall results. 
Table 7. Results from the perception test divided by listening method

\begin{tabular}{|c|c|c|c|c|c|c|}
\hline $\begin{array}{l}\text { Listening } \\
\text { method }\end{array}$ & Category & [i] & {$\left[\mathbf{i}^{\mathbf{s}}\right]$} & {$\left[\mathbf{i}^{\mathrm{r}}\right]$} & {$\left[\mathbf{i}^{\theta}\right]$} & Total \\
\hline \multirow[t]{4}{*}{ MP3 } & Answers & 242 & 242 & 242 & 242 & 968 \\
\hline & Blank answers & $\begin{array}{c}0 \\
(0 \%)\end{array}$ & $\begin{array}{c}9 \\
(3.72 \%\end{array}$ & $\begin{array}{c}6 \\
(2.48 \%)\end{array}$ & $\begin{array}{c}3 \\
(1.24 \%)\end{array}$ & $\begin{array}{c}18 / 968 \\
(1.86 \%)\end{array}$ \\
\hline & $\begin{array}{lllll}\text { Correct answers } / \text { all possible } \\
\text { answers }\end{array}$ & $\begin{array}{l}149 / 242 \\
(61.57 \%)\end{array}$ & $\begin{array}{c}47 / 242 \\
(19.42 \%)\end{array}$ & $\begin{array}{c}69 / 242 \\
(28.51 \%)\end{array}$ & $\begin{array}{c}39 / 242 \\
(16.12 \%)\end{array}$ & $\begin{array}{c}304 / 968 \\
(31.40 \%)\end{array}$ \\
\hline & $\begin{array}{l}\text { Correct answers / all possible } \\
\text { answers }- \text { blank answers }\end{array}$ & $\begin{array}{l}149 / 242 \\
(61.57 \%)\end{array}$ & $\begin{array}{c}47 / 233 \\
(20.17 \%)\end{array}$ & $\begin{array}{c}69 / 236 \\
(29.24 \%) \\
\end{array}$ & $\begin{array}{c}39 / 239 \\
(16.32 \%)\end{array}$ & $\begin{array}{c}304 / 950 \\
(32 \%) \\
\end{array}$ \\
\hline \multirow[t]{4}{*}{ Speakers } & Answers & 36 & 36 & 36 & 36 & 144 \\
\hline & Blank answers & $\begin{array}{c}1 \\
(2.77 \%) \\
\end{array}$ & $\begin{array}{c}4 \\
(11.11) \\
\end{array}$ & $\begin{array}{c}5 \\
(3.88 \%) \\
\end{array}$ & $\begin{array}{c}3 \\
(8.33 \%) \\
\end{array}$ & $\begin{array}{l}13 / 144 \\
(9.03 \%) \\
\end{array}$ \\
\hline & $\begin{array}{lllll}\begin{array}{l}\text { Correct answers } / \text { all possible } \\
\text { answers }\end{array} & & & \\
\end{array}$ & $\begin{array}{c}21 / 36 \\
(58.33 \%)\end{array}$ & $\begin{array}{c}8 / 36 \\
(22.22 \%) \\
\end{array}$ & $\begin{array}{c}15 / 36 \\
(41.66 \%)\end{array}$ & $\begin{array}{c}11 / 36 \\
(30.55 \%)\end{array}$ & $\begin{array}{c}55 / 144 \\
(38.19 \%)\end{array}$ \\
\hline & $\begin{array}{l}\text { Correct answers / all possible } \\
\text { answers }- \text { blank answers }\end{array}$ & $\begin{array}{l}21 / 35 \\
(60 \%)\end{array}$ & $\begin{array}{c}8 / 32 \\
(25 \%)\end{array}$ & $\begin{array}{c}15 / 31 \\
(48.39 \%)\end{array}$ & $\begin{array}{c}11 / 33 \\
(33.33 \%)\end{array}$ & $\begin{array}{c}55 / 131 \\
(41.98 \%)\end{array}$ \\
\hline
\end{tabular}

The group of students who performed the experiment listening to the audio from the speakers in front of the class entered a higher percentage of blank answers $(9.03 \%)$ compared to the groups who listened to the audio on individual MP3 players (1.86\%). The percentage of correct identification of [i] is slightly higher for the group who listened to the stimulus on the MP3s, while the group who listened to the audio from the speakers identified the other three realizations of /i/ better than the other groups.

Table 8. Results from the perception test for all participants.

\begin{tabular}{|l|c|c|c|c|c|}
\hline & {$[\mathbf{i}]$} & {$\left[\mathbf{i}^{\mathbf{s}}\right]$} & {$\left[\mathbf{i}^{\mathbf{r}}\right]$} & {$\left[\mathbf{i}^{\boldsymbol{\theta}}\right]$} & Total \\
\hline Answers & 278 & 278 & 278 & 278 & 1112 \\
\hline Blank answer & $2 / 278$ & $13 / 278$ & $11 / 278$ & $6 / 278$ & $32 / 1112$ \\
& $(0.72 \%)$ & $(4.68 \%)$ & $(3.96 \%)$ & $(2.16 \%)$ & $(2.88 \%)$ \\
\hline Correct answers / all possible answers & $170 / 278$ & $55 / 278$ & $84 / 278$ & $50 / 278$ & $359 / 1112$ \\
& $(61.15 \%)$ & $(19.78 \%)$ & $(30.22 \%)$ & $(17.99 \%)$ & $(32.28 \%)$ \\
\hline Correct answers / all possible answers - & $170 / 276$ & $55 / 265$ & $84 / 267$ & $50 / 272$ & $359 / 1080$ \\
blank answers & $(61.59 \%)$ & $(20.75 \%)$ & $(31.46 \%)$ & $(18.38 \%)$ & $(33.24 \%)$ \\
\hline Number of respondents & 139 & 139 & 139 & 139 & 139 \\
\hline
\end{tabular}

\subsection{Statistical analysis: Perception experiment}

One sample t-tests were run on SPSS to judge whether the correct identification of [i], $\left[\mathrm{i}^{\mathrm{s}}\right],\left[\mathrm{i}^{\mathrm{r}}\right]$, and $\left[\mathrm{i}^{\theta}\right]$ was statistically significant. It is worth noting that chance level was $25 \%$, as 
each realization of /i/ could be grouped into four categories. As such, no statistical tests were run for vowels whose correct level of identification was below chance level.

The vowel [i] was identified correctly at a rate of $61.59 \%(61.15 \%$ if we count blank answers as errors). A one sample t-test confirms that EAS speakers can identify word-final [i] correctly $(p$-value $=.000)$. This means that the identification of [i] is not due to chance; EAS speakers can distinguish $[\mathrm{i}]$ from $\left[\mathrm{i}^{\mathrm{i}}\right],\left[\mathrm{i}^{\mathrm{r}}\right]$, and $\left[\mathrm{i}^{\theta}\right]$. However, the distinctive feature of this contrast remains unidentified.

The vowel $\left[\mathrm{i}^{\mathrm{s}}\right]$ has been identified correctly in $20.75 \%$ of cases $(19.78 \%$ if we count blank answers as errors). In both cases, the level of identification is below chance level (25\%), which means that EAS speakers cannot distinguish $\left[\mathrm{i}^{\mathrm{s}}\right]$ from $[\mathrm{i}],\left[\mathrm{i}^{\mathrm{r}}\right]$, or $\left[\mathrm{i}^{\theta}\right]$.

The vowel $\left[\mathrm{i}^{\mathrm{r}}\right]$ was identified correctly in $31.46 \%$ of cases, which yielded a $p$-value $=$ $.010(30.22 \%$ if we count blank answers as errors, which has a $p$-value $=.028)$. This means that EAS speakers can distinguish $\left[\mathrm{i}^{\mathrm{r}}\right]$ from $[\mathrm{i}],\left[\mathrm{i}^{\mathrm{s}}\right]$, or $\left[\mathrm{i}^{\theta}\right]$. Interestingly, the difference between the $\mathrm{F} 2$ values for $\left[\mathrm{i}^{\mathrm{r}}\right]$ and $[\mathrm{i}],\left[\mathrm{i}^{\mathrm{s}}\right]$, or $\left[\mathrm{i}^{\theta}\right]$ were not statistically significant. Regarding $\mathrm{F} 1$, the only difference which was statistically significant was when $\left[\mathrm{i}^{\mathrm{r}}\right]$ was compared with [i]. The difference of $\mathrm{F} 1$ for $\left[\mathrm{i}^{\mathrm{r}}\right]$ is not statistically significant when compared to $\left[\mathrm{i}^{\mathrm{s}}\right]$ or $\left[\mathrm{i}^{\theta}\right]$ but the rate of identification of $\left[\mathrm{i}^{\mathrm{r}}\right]$ in complete isolation is; this might suggest that there are other cues at play other than vowel height and frontness when it comes to the correct identification of EAS /i/.

Finally, $\left[\mathrm{i}^{\theta}\right]$ was identified correctly at a rate of $18.38 \%(17.99 \%$ if we count blank answers as errors). With a rate of identification below chance level, we can confirm that EAS speakers cannot distinguish $\left[\mathrm{i}^{\theta}\right]$ from $[\mathrm{i}],\left[\mathrm{i}^{\mathrm{s}}\right]$, or $\left[\mathrm{i}^{\mathrm{r}}\right]$.

\subsection{Results: Perception experiment}

The results from the perception test suggest that EAS speakers from Western Almería can distinguish word-final /i/ from /i/ preceding deleted /-s/, /-r/, and /- $\theta /$. Likewise, EAS 
speakers can distinguish $\left[\mathrm{i}^{\mathrm{r}}\right]$ from $[\mathrm{i}],\left[\mathrm{i}^{\mathrm{i}}\right]$, and $\left[\mathrm{i}^{\theta}\right]$. A series of statistical tests discussed in Section 4.3 support these hypotheses. These results contrast with the findings reported previously for other EAS vowels. Herrero de Haro (2016) concludes that EAS speakers can identify $[\mathrm{e}],\left[\mathrm{e}^{\mathrm{s}}\right]$, and $\left[\mathrm{e}^{\mathrm{r}}\right]$ in complete isolation. Herrero de Haro (2017a) confirms that EAS speakers can identify $[\mathrm{o}]$ and $\left[\mathrm{o}^{\theta}\right]$ correctly, and Herrero de Haro $(2017 \mathrm{c})$ claims that EAS speakers can identify whether /a/ is followed or not by deleted /-s/,/-r/, and /- $\theta /$, but that these speakers cannot identify an underlying /-s/, /-r/, or /- $\theta /$ after /a/.

According to the statistical analyses performed in Section 4.3, the only two realizations of /i/ that EAS speakers can identify in isolation without contextual help are [i] $(p$-value $=.000)$ and $\left[\mathrm{i}^{\mathrm{r}}\right](p$-value $=.010)$. The correct identification of [i] could be due to a lower $\mathrm{F} 1$ value for this vowel than for $\left[\mathrm{i}^{\mathrm{s}}\right],\left[\mathrm{i}^{\mathrm{r}}\right]$, and $\left[\mathrm{i}^{\theta}\right]$. This difference between a lower $\mathrm{F} 1$ for $[i]$ and a higher $F 1$ for $\left[i^{\mathrm{s}}\right],\left[\mathrm{i}^{\mathrm{i}}\right]$, and $\left[\mathrm{i}^{\theta}\right]$ could help EAS speakers differentiate between word-final $/ \mathbf{i} /$ and $/ \mathbf{i} /$ preceding underlying /-s/, /-r/, and /- $\theta /$. As such, the contrast [i] vs $\left[\mathrm{i}^{\mathrm{s}}\right]$ might be solved by identifying that a consonant has been deleted, rather than by identifying the quality of $\left[\mathrm{i}^{\mathrm{s}}\right]$. This was already proposed by Navarro Tomás (1939) but had not been analyzed with perceptual data until now. Considering this, contrasts such as [i] vs [i $\left.{ }^{\mathrm{s}}\right]$, [i] vs $\left[\mathrm{i}^{\mathrm{r}}\right]$ or $[\mathrm{i}]$ vs $\left[\mathrm{i}^{\theta}\right]$ could be resolved in the mind of an EAS speaker by identifying (or not) an underlying consonant in each pair of vowels. While $\left[\mathrm{i}^{\mathrm{s}}\right],\left[\mathrm{i}^{\mathrm{r}}\right]$, and $\left[\mathrm{i}^{\theta}\right]$ are all subject to vowel opening and have a higher F1 than [i], EAS speakers can only identify $\left[^{\mathrm{r}}\right]$ in complete isolation. In a strict sense of the word, that could mean that $\left[\mathrm{i}^{\mathrm{r}}\right]$ is, in fact, a vowel phoneme in EAS; however, Bybee (2001: 55) explains how some phonetic features can be used by speakers to contrast sounds, so a much more detailed analysis is needed before we can conclude which ones are the vowel phonemes of EAS. The vowel inventory of EAS and the cognitive mechanisms behind the identification of these call for further research; however, they fall outside the remit of the present paper. 
It is not possible for the distinctive feature in operation in the contrasts discussed above to be post-aspiration, as posited for WAS by Torreira (2007b) and by Ruch and Harrington (2014), as none of the 383 tokens of /i/ analyzed in the present study exhibited aspiration. Length was not measured for the 383 tokens of /i/ studied in this paper but it could be the distinctive feature in operation in EAS; this has been posited for other varieties of Spanish (e.g. for Miami-Cuban Spanish by Hammond 1978; for Puerto Rican Spanish by Figueroa 2000). Alternatively, the contrast $\left[\mathrm{i}^{\mathrm{r}}\right]$ vs $\left[\mathrm{i}^{\mathrm{s}}\right]$ and $\left[\mathrm{i}^{\mathrm{r}}\right]$ vs $\left[\mathrm{i}^{\theta}\right]$ might be based on suprasegmental differences, as posited by Contreras Jurado (1975). This could be backed by the fact that EAS speakers could distinguish $\left[\mathrm{i}^{\mathrm{r}}\right]$ from $[\mathrm{i}],\left[\mathrm{i}^{\mathrm{s}}\right]$, and $\left[\mathrm{i}^{\theta}\right]$ despite a difference of F1 and F2 which was not statistically significant in all cases (when comparing $\left[\mathrm{i}^{\mathrm{r}}\right]$ with $\left[\mathrm{i}^{\mathrm{s}}\right]$ and $\left.\left[i^{\theta}\right]\right)$.

The correct identification of $\left[i^{\mathrm{r}}\right]$, however, raises some further questions. F1 and F2 values for $\left[\mathrm{i}^{\mathrm{r}}\right]$ are not statistically different to those of $\left[\mathrm{i}^{\mathrm{s}}\right]$ and $\left[\mathrm{i}^{\theta}\right]$; yet, $\left[\mathrm{i}^{\mathrm{r}}\right]$ has been identified correctly in around $11-13 \%$ more cases than $\left[\mathrm{i}^{\mathrm{s}}\right]$ and $\left[\mathrm{i}^{\theta}\right]$. In EAS, $\left[\mathrm{i}^{\mathrm{r}}\right]$ is more open than the other three realizations of $/ \mathrm{i} /\left([\mathrm{i}],\left[\mathrm{i}^{\mathrm{s}}\right]\right.$, and $\left.\left[\mathrm{i}^{\theta}\right]\right)$ and $\left[\mathrm{i}^{\mathrm{r}}\right]$ corresponds to the pronunciation of $i r$ 'to go', which is a high frequency word. This vowel also corresponds to the ending of the infinitive form of verbs of the third conjugation, so learning to identify the open character of word-final $\left[\mathrm{i}^{\mathrm{r}}\right]$ could be a consequence of continuous exposure to this sound, as explained by the frequency effect (Bybee 2003: 60-62). However, [i $\left.\mathrm{i}^{\mathrm{s}}\right]$ is also a common sound in Spanish as it is the ending of the present tense of third conjugation verbs in the you informal pl. form and EAS speakers could not identify it correctly. Thus, I do not believe that frequency could explain the correct identification of $\left[\mathrm{i}^{\mathrm{r}}\right]$. The distinctive feature at play when identifying $\left[\mathrm{i}^{\mathrm{r}}\right]$, however, could be another suprasegmental element not identified yet. This would explain why EAS speakers can distinguish $\left[\mathrm{i}^{\mathrm{r}}\right]$ from $\left[\mathrm{i}^{\mathrm{i}}\right]$ and $\left[\mathrm{i}^{\theta}\right]$ despite a lack of difference in the $\mathrm{F} 1$ or F2, as shown in the data in Tables 5 and 6. 


\section{Discussion}

\subsection{Discussion: Acoustic analysis}

An acoustic analysis of /i/ word-finally and before underlying /-s/, /-r/, and /- $\theta$ / shows that the deletion of these three consonants changes the quality of the preceding /i/ to a different extent. A statistical analysis, however, suggests that the only differences which are statistically significant are those of word-final /i/ vs those of /i/ before underlying /-s/, /-r/, and $/-\theta /$; the differences between the $\mathrm{F} 1$ and $\mathrm{F} 2$ values of $\left[\mathrm{i}^{\mathrm{s}}\right],\left[\mathrm{i}^{\mathrm{r}}\right]$, and $\left[\mathrm{i}^{\theta}\right]$ are not statistically significant. This means that EAS has two distinct realizations of /i/ word-finally: [i] and $\left[i^{\mathrm{s} / \mathrm{r} / \theta}\right]$. This contrasts with the findings presented in Herrero de Haro $(2016,2017 \mathrm{a}, 2017 \mathrm{c})$, where /e/, /o/, and /a/ were found to have four distinct realizations: each vowel word-finally and before underlying /-s/, /-r/, and /- $\theta /$. The results from the present paper show that $/ \mathrm{i} /$ opens before underlying /-s/, which supports the findings of Martínez Melgar (1986, 1994) and Peñalver Castillo (2006). Additionally, although vowel opening before these three consonants had not been carried out before, having fewer distinct realizations of /i/ than of /e/, /o/, and /a/ seems to present some correlation with the findings of previous researchers (e.g. Sanders 1998; Henriksen 2017), who identified vowel opening in EAS mid and low vowels before deleted /-s/, but not in high vowels; the correlation would be in terms of /i/ opening before underlying consonants but showing fewer distinct realizations than the mid or low vowels. F1 and F2 values of /i/ in these four contexts can be compared to those of /e/, /a/, and /o/ in Table 9. 
Table 9. Formant values for EAS /i/, /e/, /a/, and /o/ word-finally and before underlying /-s/, /-r/, and /- $\theta /$.

Values for /e/, /o/, and /a/ taken from Herrero de Haro (2016, 2017a, 2017c), respectively.

\begin{tabular}{|c|c|c|c|c|c|}
\hline Vowel & Realization & F1 & F2 & $\begin{array}{c}\text { Stan. } \\
\text { Dev. F1 }\end{array}$ & $\begin{array}{c}\text { Stan. } \\
\text { Dev. F2 }\end{array}$ \\
\hline \multirow[t]{4}{*}{$/ \mathbf{i} /$} & [i] & 369 & 2154 & 47.08 & 221.12 \\
\hline & {$\left[\mathbf{i}^{\mathrm{s}}\right]$} & 402 & 2218 & 43.69 & 258.98 \\
\hline & {$\left[\mathrm{i}^{\mathrm{r}}\right]$} & 408 & 2186 & 44.32 & 237.54 \\
\hline & {$\left[\mathbf{i}^{\theta}\right]$} & 393 & 2265 & 43.05 & 293.98 \\
\hline \multirow[t]{4}{*}{$/ \mathbf{e} /$} & {$[\mathrm{e}]$} & 474 & 2048 & 12.55 & 88.51 \\
\hline & {$\left[\mathrm{e}^{\mathrm{s}}\right]$} & 597 & 1803 & 12.91 & 137.04 \\
\hline & {$\left[\mathrm{e}^{\mathrm{r}}\right]$} & 641 & 1830 & 31.52 & 85.34 \\
\hline & {$\left[\mathrm{e}^{\theta}\right]$} & 602 & 1730 & 25.97 & 224.50 \\
\hline \multirow[t]{4}{*}{$/ \mathbf{a} /$} & [a] & 679 & 1451 & 78.91 & 156.14 \\
\hline & {$\left[a^{s}\right]$} & 724 & 1471 & 79.98 & 167.79 \\
\hline & {$\left[\mathbf{a}^{\mathrm{r}}\right]$} & 753 & 1525 & 81.10 & 191.28 \\
\hline & {$\left[\mathbf{a}^{\theta}\right]$} & 721 & 1383 & 82.66 & 113.55 \\
\hline \multirow[t]{4}{*}{$/ 0 /$} & [o] & 489 & 1212 & 42.98 & 233.08 \\
\hline & {$\left[o^{s}\right]$} & 587 & 1239 & 59.35 & 234.24 \\
\hline & {$\left[\mathbf{o}^{\mathrm{r}}\right]$} & 638 & 1265 & 66.7 & 222.86 \\
\hline & {$\left[\mathbf{o}^{\theta}\right]$} & 607 & 1110 & 62.37 & 133.08 \\
\hline
\end{tabular}

It is not easy to find the articulatory explanation for these changes in the F1 and F2 and this falls outside the remit of the present paper; however, it is worth pointing out at least two options as a way of identifying future lines of research. One of them is the possibility of what we could refer to as underlying coarticulation, in which the vowels partially assimilate towards the place of articulation of a deleted consonant. This would explain that $/ \mathrm{i} /, / \mathrm{a} /$, and /e/ become more fronted before underlying /-s/ and /-r/; however, /e/ shows a decrease in its F2 value in the same context. Likewise, /i/ has a higher F2 before underlying /- $\theta /$, while /e/, 
/a/ and /o/ have a lower F2. Underlying coarticulation does not seem to explain vowel alteration before underlying consonants in EAS as the same underlying consonant seems to pull different vowels into different directions despite these vowels being pronounced very close to each other (e.g. /i/ and /e/). The second possibility could be explained in terms of a functional hypothesis. As the changes in the F1 and F2 of /i/, /e/, /a/ and /o/ show, the movements of each of the realizations of these vowels move towards an empty place in the vowel space, preventing vowel merging; this could be seen as an attempt to maintain in the surface structure information which is semantically relevant (Kiparsky 1982: 127). Deleting /-s/ may seem to oppose such functional hypothesis; however, as Poplack (1979) concludes, /-s/ is deleted less frequently in Spanish noun clauses and the redundant character of plural /-s/ means that there will be no room for misunderstanding in many cases when /-s/ is deleted. As Vida Castro (2014: 27) points out, this is also the case for other varieties of Spanish which exhibit/-s/ deletion; Vida Castro (2014: 27) quotes the following examples: Cedergren (1972: 46), Poplack (1979: 87), López Morales (1983: 54-55), Alba (1990: 102), Samper Padilla (1990: 93-94), and Calero Fernández (1993: 129). It is worth remembering, however, that all tokens used for the perception test in the current study were presented in complete isolation.

A functional hypothesis might explain EAS vowel alteration. The vowel /i/ becomes more open and fronted when it precedes an underlying /-s/, /-r/, or /- $\theta /$ so that it does not enter the acoustic space of /e/; /e/ opens and backs and it does not enter the acoustic space of /i/ or /a/. The biggest distance between the F2 of the vowels considered is that between /e/ and /a/, and /e/ is the vowel which shows the greatest change in F2 before an underlying consonant. Likewise, /o/ is close to /a/ in terms of frontness and it only suffers minimal fronting when it precedes a deleted /-s/ or /-r/ and minimal backing when it precedes a deleted /- $\theta /$; this could be to avoid entering the acoustic space of $/ \mathrm{a} /$ and $/ \mathrm{u} /$. Finally, the realizations of $/ \mathrm{a} /$ before the underlying consonants considered here also suffer minimal backing or fronting, once again, 
maintaining certain distance with other realizations of /e/ and /o/. Following the suggestions of one anonymous reviewer, these analyses have been included to offer a possible explanation for the behaviour of EAS vowels; however, identifying the trigger for such movements in the vowel space falls outside the remit of the present paper.

\subsection{Discussion: Perception study}

The statistical analysis of the results from the perception test how that EAS speakers can identify whether or not $/ \mathrm{i} / \mathrm{is}$ followed by an underlying /-s/, /-r/, or /- $\theta /$ without any contextual help. Furthermore, EAS speakers can identify $[\mathrm{i}]$ and $\left.\mathrm{i}^{\mathrm{r}}\right]$ in isolation word-finally. They can also distinguish $\left[\mathrm{i}^{\mathrm{r}}\right]$ from $[\mathrm{i}],\left[\mathrm{i}^{\mathrm{s}}\right]$, and $\left[\mathrm{i}^{\theta}\right]$ despite the fact that the difference between the F1 and F2 of these three realizations are not statistically significant. This suggests that the identification of these three realizations of /i/ when they precede an underlying vowel are not due to differences of height or frontness, but to another feature; it is hypothesized that the most likely candidates are vowel lengthening or an unidentified suprasegmental element.

EAS speakers can also identify whether or not /e/, /o/, and /a/ are followed by an underlying /-s/, /-r/, or /- $\theta /$ (Herrero de Haro 2016, 2017a, 2017c). These speakers can distinguish, perceptually, $\left[\mathrm{e}^{\mathrm{s}}\right]$ and $\left[\mathrm{e}^{\mathrm{r}}\right]$ from $\left[\mathrm{e}^{\theta}\right]$ (Herrero de Haro 2016). As $\left[\mathrm{e}^{\mathrm{s}}\right]$ and $\left[\mathrm{e}^{\mathrm{r}}\right]$ are more common than $\left[\mathrm{e}^{\theta}\right]$ in Spanish, it could be argued that frequency effects (Bybee 2001: 11) are at play in this distinction. However, Herrero de Haro (2017a) concludes that, when it comes to $/ \mathrm{o} /$ preceding underlying /-s/, /-r/, and /- $\theta /$, the only vowel that EAS speakers can identify in isolation is $\left[\mathrm{o}^{\theta}\right]$, and this realization of $/ \mathrm{o} /$ is much less frequent than $\left[\mathrm{o}^{\mathrm{s}}\right]$ or $\left[\mathrm{o}^{\mathrm{s}}\right]$, which suggests that there is no relationship between the frequency of a vowel realization and the ability of EAS speakers to identify it. Another important point to notice is that, according to Herrero de Haro $(2016,2017 \mathrm{a}, 2017 \mathrm{c})$ and to the data presented in the current study, /i/ seems to be the only vowel for which EAS speakers can identify different realizations despite F1 and F2 differences not being statistically significant. This does not mean that $/ \mathbf{i} /$ is the only 
vowel where suprasegmentals seem to be in operation, but it could mean that F1 and F2 changes in /e/, /o/, and /a/ when they preceded an underlying consonant are covariants, in the sense explained in Idemaru and Guion (2008) for Japanese geminates. It is also possible that there are various features at play in the identification of EAS, as it is the case for the identification of $[\mathrm{ts}]$ and $[\mathrm{t}]]$ in the Spanish spoken in Malaga (Vida Castro and Villena Ponsoda 2016).

According to some authors (e.g. Navarro Tomás 1939; Fernández Sevilla 1980), the cognitive processes behind the identification of vowels word-finally and before underlying consonant does not seem to be based on identifying the quality of the vowel, but on identifying whether or not a consonant has been deleted.

Identifying the distinctive feature of the different realizations of /i/ and describing the cognitive process behind their identification falls outside the remit of the present paper; however, they highlight the need for further research on the topic.

\section{Conclusion}

This paper has investigated EAS /i/ from the point of view of production and perception and it has complemented and supplemented the existing literature on word-final consonant deletion in this variety of Spanish.

Firstly, 383 tokens of /i/ were analyzed to establish whether word-final /s/, /r/, and / $/$ / deletion causes different changes to the quality of a preceding /i/. It has been explained in Section 3 how /i/ has a different quality word-finally and when it is followed by underlying /-s/, /-r/, and /- $\theta /$; however, a statistical analysis suggests that the difference between the F1 and the $\mathrm{F} 2$ of $\left[\mathrm{i}^{\mathrm{i}}\right],\left[\mathrm{i}^{\mathrm{r}}\right]$, and $\left[\mathrm{i}^{\theta}\right]$ is not statistically significant. This is different to the situation found for /e/, /o/, and /a/, where each of these vowels presented four different allophones: /e/, /o/, and /a/ word-finally and before underlying /-s/, /-r/, and /- $\theta /$ (Herrero de Haro 2016, 2017a, 2017c). 
Following the acoustic analysis, a perception test was carried out where EAS speakers from Western Almería had to identify $[\mathrm{i}],\left[\mathrm{i}^{\mathrm{s}}\right],\left[\mathrm{i}^{\mathrm{r}}\right]$, and $\left[\mathrm{i}^{\theta}\right]$. The results from the perception test show that EAS speakers can identify whether or not /i/ is followed by an underlying /-s/, /-r/, or / $-\theta /$. This has also been reported to be the case for /e/, /o/, and /a/ (Herrero de Haro 2016, 2017a, 2017c). Furthermore, EAS speakers from Western Almería can distinguish [i $\left.{ }^{\mathrm{r}}\right]$ from $\left[\mathrm{i}^{\mathrm{s}}\right]$ and $\left[\mathrm{i}^{\theta}\right]$. These results are similar to the ones reported in Herrero de Haro (2016, 2017a), where the participants could differentiate between /e/ and /o/ preceding some underlying consonants: $\left[\mathrm{e}^{\mathrm{s}}\right]$ from $[\mathrm{e}],\left[\mathrm{e}^{\mathrm{r}}\right]$, and $\left[\mathrm{e}^{\theta}\right] ;\left[\mathrm{e}^{\mathrm{r}}\right]$ from $[\mathrm{e}],\left[\mathrm{e}^{\mathrm{s}}\right]$, and $\left[\mathrm{e}^{\theta}\right]$; and $\left[\mathrm{o}^{\theta}\right]$ from $[\mathrm{o}],\left[\mathrm{o}^{\mathrm{s}}\right]$, and $\left[\mathrm{o}^{\mathrm{r}}\right]$.

As explained in Section 3.3, the differences between the F1 and F2 of $\left[\mathrm{i}^{\mathrm{s}}\right],\left[\mathrm{i}^{\mathrm{r}}\right]$, and $\left[\mathrm{i}^{\theta}\right]$ were not statistically significant; thus, it seems reasonable to assume that the cue to distinguish $\left[\mathrm{i}^{\mathrm{r}}\right]$ from $\left[\mathrm{i}^{\mathrm{s}}\right]$ and from $\left[\mathrm{i}^{\theta}\right]$ does not lie in the height and/or frontness of the vowels. Considering this, it could be argued that the distinctive feature distinguishing $\left[\mathrm{i}^{\mathrm{r}}\right]$ from $\left[\mathrm{i}^{\mathrm{s}}\right]$ and $\left[i^{\theta}\right]$ could be vowel length or another suprasegmental feature. I believe that the changes of quality that $/ \mathrm{i} /$ is subject to before $/-\mathrm{s} /, /-\mathrm{r} /$, and $/-\theta /$ deletion are also in operation wordmedially, which would allow EAS speakers to distinguish minimal pairs such as islandés [ịt:añ 'dẹ] 'Icelander' and irlandés [ịl:an' dẹ] 'Irish'.

Considering the data presented in this paper, it can be concluded that:

1) /i/ opens before underlying /-s/, /-r/, and /- $\theta /$.

2) the deletion of $/-\mathrm{s} /, /-\mathrm{r} /$, and $/-\theta /$ changes the quality of a preceding $/ \mathrm{i} /$, but as a group, not differentially; the difference between $[\mathrm{i}]$ and $\left[\mathrm{i}^{\mathrm{s}}\right],\left[\mathrm{i}^{\mathrm{r}}\right]$, and $\left[\mathrm{i}^{\theta}\right]$ is statistically significant but the differences between the $\mathrm{F} 1$ and $\mathrm{F} 2$ of $\left[\mathrm{i}^{\mathrm{s}}\right],\left[\mathrm{i}^{\mathrm{r}}\right]$, and $\left[\mathrm{i}^{\theta}\right]$ are not.

3) EAS speakers can identify whether or not /i/ is followed by an underlying /-s/, /-r/, or $/-\theta /$. 
4) EAS speakers can identify [i] and [i $\left.{ }^{\mathrm{r}}\right]$ in isolation word-finally, distinguishing [i] from $\left[\mathrm{i}^{\mathrm{s}}\right],\left[\mathrm{i}^{\mathrm{r}}\right]$, and $\left[\mathrm{i}^{\theta}\right]$; and $\left[\mathrm{i}^{\mathrm{r}}\right]$ from $[\mathrm{i}],\left[\mathrm{i}^{\mathrm{s}}\right]$, and $\left[\mathrm{i}^{\theta}\right]$.

5) the cue to distinguish $\left[\mathrm{i}^{\mathrm{r}}\right]$ from $[\mathrm{i}],\left[\mathrm{i}^{\mathrm{s}}\right]$, and $\left[\mathrm{i}^{\theta}\right]$ does not lie in the height or frontness of the vowel, but in another feature. The most likely candidates are vowel lengthening or a suprasegmental element not identified yet.

\section{Acknowledgements}

I would like to thank Elisabeth Duursma, the High-Output Writing Group from The University of Wollongong, the editor of the Australian Journal of Linguistics, and the anonymous reviewers for their comments on earlier drafts of this work and for their help to improve the quality of this paper. I would also like to thank staff and students at the following schools for helping me gather the necessary materials for this research project: I.E.S. Fuente Nueva (El Ejido); I.E.S. Santo Domingo (El Ejido); C.E.I.P. Laimún (El Ejido); I.E.S. Mar Azul (Balerma); I.E.S. Virgen del Mar (Adra); and I.E.S. Abdera (Adra).

\section{Disclosure Statement}

No potential conflict of interest was reported by the author. 


\section{References}

Alarcos Llorach E 1958 'Fonología y fonética (a propósito de las vocales andaluzas)' Archivum: Revista de la Facultad de Filología 8: 193-205.

Alarcos Llorach E 1976 Fonología española B.R.H. 4 ed. Gredos Madrid.

Alarcos Llorach E 1983 'Más sobre vocales andaluzas' in Philologica hispaniensia: in honoren Manuel Alvar Editorial Gredos: 49-56.

Alba O 1990 Variación fonética y diversidad social en el español dominicano de Santiago Pontífica Universidad Católica Madre y Maestra Santiado.

Alvar M 1955 'Las encuestas del "Atlas lingüístico de Andalucía"' Revista de Dialectología y Tradiciones Populares 11: 231-274.

Alvar M, A Llorente \& G Salvador 1973 Atlas lingüístico y etnográfico de Andalucía Universidad de Granada. Consejo superior de investigaciones científicas.

Audacity T 2014 Audacity (Version 2.0. 2).

Bishop JB 2007 Incomplete neutralization in Eastern Andalusian Spanish: Perceptual consequences of durational differences involved in s-aspiration Paper presented at Proceedings of the XVI International Congress of Phonetic Sciences, Saarbrücken, Germany.

Blecua Falgueras B 2005 'Variación acústica de la vibrante en posición implosiva' in Filología y lingüistica: estudios ofrecidos a Antonio Quilis CSIC/UNED/Universidad de Valladolid Madrid: 97-111.

Boersma P \& D Weenink 2016 Praat: doing phonetics by computer $<\underline{\text { http://www.praat.org/>. }}$

Bradley TG 2014 'Optimality Theory and Spanish Phonology' Language and Linguistics Compass 8(2): 65-88.

Bybee J 2001 Phonology and language use Cambridge University Press Cambridge, UK. 
Calero Fernández MÁ 1993 Estudio sociolingüístico del habla de Toledo Pagès editors Lérida.

Carlson KM 2012 'An Acoustic and Perceptual Analysis of Compensatory Processes in Vowels Preceding Deleted Post-Nuclear /s/ in Andalusian Spanish' Concentric: Literacy \& Cultural Studies 38 (1): 39-67.

Cedergren H 1972 Interplay of Social and Linguistic Factors in Panamá Unpublished thesis, Cornell University.

Cerdà Massó R 1992 'Nuevas precisiones sobre el vocalismo del andaluz oriental' Lingüística Española Actual 14(1): 165-182.

Contreras Jurado A 1975 'Vocales abiertas del plural en andaluz oriental, fonemas o prosodemas' Yelmo: 23-25.

Corbin L 2006 The phonetics and phonology of s-lenition and vowel laxing in eastern Andalusian Spanish Unpublished thesis, Dissertation. Williams College, Williamstown, Massachusetts.

Fernández Sevilla J 1980 'Los fonemas implosivos en español' Thesaurus 35: 456-505.

Figueroa N 2000 An acoustic and perceptual study of vowels preceding deleted post-nuclear /s/ in Puerto Rican Spanish. Paper presented at Hispanic linguistics at the turn of the millennium.

García Marcos FJ 1987 'El segmento fónico vocal+S en ocho poblaciones de la costa granadina' Epos: Revista de filología (3): 155-180.

Gerfen C \& K Hall 2001 Coda aspiration and incomplete neutralization in Eastern Andalusian Spanish.

Hammond R 1978 'An experimental verification of the phonemic status of open and closed vowels in Caribbean Spanish' in H López Morales (ed.) Corrientes actuales en la dialectología del Caribe hispánico Universidad de Puerto Rico Rio Piedras: 33-125. 
Henriksen N 2017 'Patterns of vowel laxing and harmony in Iberian Spanish: Data from production and perception' Journal of Phonetics 63: 106-126.

Henriksen NC \& EW Willis 2010 Acoustic characterization of phonemic trill production in Jerezano Andalusian Spanish Paper presented at 4th Conference on Laboratory Approaches to Spanish Phonology.

Herrero de Haro A 2016 'Four mid front vowels in Western Almería: The effect of /s/, /r/, and /9/ deletion in Eastern Andalusian Spanish' Zeitschrift für Romanische Philologie 132 (1): $118-148$.

Herrero de Haro A 2017a 'Four mid back vowels in Eastern Andalusian Spanish: The effect of $/ \mathrm{s} /, / \mathrm{r} /$, and $/ \theta /$ deletion on preceding $/ \mathrm{o} /$ in the town of El Ejido' Zeitschrift für Romanische Philologie 133 (1): 82 - 114.

Herrero de Haro A 2017 b 'The phonetics and phonology of Eastern Andalusian Spanish: A review of literature from 1881 to 2016 ' Ikala 22 (2): 313-357.

Herrero de Haro A 2017c 'The vowel /a/ before underlying /-s/, /-r/, and /- $\theta$ / in El Ejido: Four low central vowels in Eastern Andalusian Spanish' Dialectologia et Geolinguistica 25: $23-50$.

Herrero de Haro A Under review The vowel $/ \mathrm{u} /$ before deleted word-final $/ \mathrm{s} /, / \mathrm{r} /$, and $/ \theta /$ in Eastern Andalusian Spanish.

Herrero de Haro A and J Hajek In press 'Illustrations of the IPA: Eastern Andalusian Spanish' Journal of the International Phonetic Association.

Idemaru K \& SG Guion 2008 'Acoustic covariants of length contrast in Japanese stops' Journal of the International Phonetic Association 38(2): 167-186.

Jiménez Fernández R 1999 El andaluz Arco/Libros Madrid. 
Jiménez J \& M-R Lloret 2007 Andalusian vowel harmony: Weak triggers and perceptibility Paper presented at workshop "Harmony in the Languages of the Mediterranean", University of Aegean, Rhodes, Greece.

kiparsky P 1982 Explanation in Phonology Floris Dordrecht.

López Morales H 1983 Estratificación social del español de San Juan de Puerto Rico Universidad Nacional Autónoma de México México.

López Morales H 1984 'Desdoblamiento fonológico de las vocales en el andaluz oriental: reexamen de la cuestión' Revista española de lingüística 14(1): 85-97.

Martínez Celdrán E 1995 'En torno a las vocales del español: análisis y reconocimiento' Estudios de fonética experimental 7: 195-218.

Martínez Melgar A 1986 'Estudio experimental sobre un muestreo de vocalismo andaluz' Estudios de fonética experimental 2: 198-248.

Martínez Melgar A 1994 'El vocalismo del andaluz oriental' Estudios de fonética experimental 6: 11-64.

Mondéjar Cumpián J 1979 'Diacronía y sincronía en las hablas andaluzas' Lingüistica española actual 1(2): 375-402.

Monroy R \& J Hernández Campoy 2015 'Illustrations of the IPA: Murcian Spanish' Journal of the International Phonetic Association 45(2): 229-240.

Moya Corral JA 2010 El oriente andaluz y el español común Paper presented at XVI Jornadas sobre la lengua española y su enseñanza, Universidad de Granada.

Navarro Tomás T 1938 'Dédoublement de phonemes dans le dialecte andalou' Travaux de Cercle Linguistique de Prague 8: 184-186.

Navarro Tomás T 1939 'Desdoblamiento de fonemas vocálicos' Revista de filologia hispánica 1: $165-167$. 
Navarro Tomás T, AM Espinosa \& L Rodríguez Castellano 1933 'La frontera del andaluz' Revista de Filología Española 20: 225 - 277.

O'Neill P 2010 'Variación y cambio en las consonantes oclusivas del español de Andalucía' Estudios de Fonética Experimental 19: 11-41.

Peñalver Castillo M 2006 'El habla de Cabra: situación actual' Anuario de estudios filológicos (29): $247-253$.

Poplack S 1979 Function and Process in a Variable Phonology Unpublished thesis, University of Pensilvania.

Quilis A 1981 Fonética acústica de la lengua española B.R.H. Editorial Gredos Madrid.

Quilis A \& M Esgueva 1983 'Realización de los fonemas vocálicos españoles en posición fonética normal' in M Esgueva \& M Cantarero (eds) Estudios de fonética: 159-252.

Regan B 2017 'A study of ceceo variation in Western Andalusia (Huelva)' Studies in Hispanic and Lusophone linguistics 10(1): 119-160.

Rodríguez-Castellano L \& A Palacio 1948a 'Contribución al estudio del dialecto andaluz: El Habla de Cabra' Revista de Dialectología y Tradiciones Populares 4(3): 387-418.

Rodríguez-Castellano L \& A Palacio 1948b 'Contribución al estudio del dialecto andaluz: El Habla de Cabra' Revista de Dialectología y Tradiciones Populares 4(4): 570-599.

Ruch H \& J Harrington 2014 'Synchronic and diachronic factors in the change from preaspiration to post-aspiration in Andalusian Spanish' Journal of Phonetics 45: 12-25.

Salvador G 1957 'El habla de Cúllar-Baza. Contribución al estudio de la frontera del andaluz' Revista de Filología Española 41: 161-252.

Salvador G 1977 'Unidades fonológicas vocálicas en andaluz oriental' Nueva Revista de Filología Hispánica 7: 1-23.

Samper Padilla JA 1990 Estudio sociolingüístico del español de Las Palmas de Gran Canaria La Caja de Canarias Las Palmas de Gran Canaria. 
Sanders BP 1994 Andalusian vocalism and related processes Unpublished thesis, University of Illinois at Urbana-Champaign.

Sanders BP 1998 'The eastern Andalusian vowel system: Form and structure' Rivista di lingüistica 10(1): 109-136.

Tejada Giráldez M 2012 'Los factores lingüísticos de la /-s/ implosiva en el nivel de estudios altos de Granada'.

Torreira F 2007a Coarticulation between aspirated-s and voiceless stops in Spanish: An interdialectal comparison Paper presented at Selected proceedings of the 9th Hispanic Linguistics Symposium.

Torreira F 2007b 'Pre-and postaspirated stops in Andalusian Spanish' in P Prieto, J Mascaró \& MJ Solé (eds) Segmental and Prosodic Issues in Romance Phonology Benjamins Amsterdam: 67-82.

Torreira F 2012 'Investigating the nature of aspirated stops in Western Andalusian Spanish' Journal of the International Phonetic Association 42(1): 49-63.

Valeš M 2014 'Panorama de la sociolingüística andaluza' Linguistica Pragensia 24(1): 45-54.

Vida Castro M 2004 Estudio sociofonológico del español hablado en la ciudad de Málaga: condicionamientos sobre la variación de/-s/en la distensión silábica Publicaciones de la Universidad de Alicante Alicante.

Vida Castro M \& JA Villena Ponsoda 2016 'Percepción y análisis de pistas en la discriminación alofónica. Fusión y escisión en el estudio sociolingüístico de la ciudad de Málaga' in AM Fernández-Planas (ed.) 53 reflexiones sobre aspectos de la fonética y otros temas de lingüistica Laboratori de Fonètica Barcelona: 129 - 137.

Villena Ponsoda JA 1987 Forma, sustancia y redundancia contextual. El caso del vocalismo del español andaluz Universidad de Málaga Málaga. 
Villena Ponsoda JA 2000 'Identidad y variación lingüística: Prestigio nacional y lealtad vernacular en el español hablado en Andalucía' in G Bossong \& F Báez de Aguilar González (eds) Identidades Lingüísticas en la España Autonómica Iberoamericana Vervuert Madrid: 107-150.

Villena Ponsoda JA 2008 'Sociolinguistic patterns of Andalusian Spanish ' International Journal of the Sociology of Language (193/194): 139-160.

Wulff F 1889 'Un chapitre de phonétique andalouse.' in Recueil de mémoires philologiques présenté à Monsieur Gaston Paris L'imprimerie centrale Stockholm: 211-260.

Zubizarreta ML 1979 'Vowel Harmony in Andalusian Spanish' Papers on Syllable Structure, Metrical Structure and Harmony Processes. MIT Working Papers in Linguistics 1: 111. 


\section{Appendix}

Hoja de respuestas. Experimento 0

Hoja de respuestas. Experimento 0

Datos personales: Hombre Mujer

Edad:

¿En qué pueblo vives?

Si no has vivido en ese pueblo desde que tienes 4 años, di en qué pueblo vivías antes y cuánto tiempo llevas en el pueblo en el que vives ahora:

Señala con un círculo la respuesta correcta. Si cometes un error, tacha la respuesta incorrecta y señala con un círculo la respuesta correcta.

\section{is}

is

is

is

is

is 